\title{
Line $\times$ Tester analysis for Yield and its Attributes in Sesame (Sesamum indicum L.)
}

\author{
M. S. Hassan and H. Kh. A. Rehab* \\ Agronomy Department, Faculty of Agriculture, South Valley \\ University, Qena and "Oil Crops Department, Field Crops \\ Research Institute, ARC, Cairo, Egypt.
}

\begin{abstract}
7 HIS RESEARCH work was conducted at Shandaweel Research Station, Sohag, Egypt, to study the combing ability and heterosis for yield and its attributes via Line $\times$ Tester analysis in sesame. Line $\times$ Tester mating design was applied in 2012 season using seven lines and four testers. In the two summers season 2013 and 2014, twentyeight $F_{1}$ hybrids, their parents and one commercial variety (Shandaweel 3) as a check were evaluated. Mean squares due to genotypes and years via combined analysis for the two years were highly significant for all studied traits, except each of 1000-seed weight and oil percentage across years. Also, mean squares due to the interaction between genotypes $\times$ years were highly significant for all the studied traits, except days to $50 \%$ flowering, branches plant ${ }^{-1}$ and 1000 -seed weight. The analysis revealed that high significant differences were found among crosses and lines for all the studied traits over the two years. Likewise, it appeared high significant differences among the four testers for all traits, except for 1000 -seed weight. High significant variances were detected for line $x$ tester interaction over years for all studied traits. In this context, results showed that significant and highly significant differences were found for all the studied traits for the interactions; crosses $\times$ year (except for length of fruiting zone, branches plant ${ }^{-1}$ and1000-seed weight), tester $x$ year (except for height of the first capsule, number of branches plant ${ }^{-1}$ and 1000 -seed weight) and parents $\times$ crosses $\times$ year (except for days to $50 \%$ flowering, number of branches plant ${ }^{-1}$, capsule length, 1000-seed weight and oil percentage). In general, the four crosses Giza32 × N.A.372, Shandaweel $2000 \times$ Local 176, Shandaweel $2000 \times$ H. 68 Family 21 and Shandaweel $2000 \times$ N.A.652 were found to be the heaviest in most of the studied traits compared to their better parents. The parents N. A. 372, H.68 family 21 and Giza 32 were good combiners for improvement most studied traits. Also, desirable SCA effects were obtained for most studied traits. The crosses; Shandaweel $3 \times$ local 176 and Shandaweel $2000 \times$ N. A. 96 had the maximum SCA desirable effects for earliness. However, for seed yield plant $^{-1}$ the crosses; Shandaweel $3 \times$ N. A. 96, Shandaweel $2000 \times$ Local 176, Giza $32 \times$ N. A. 372, Sohag $1 \times$ Local 166 and Sohag $1 \times$ H. 68 Family 21 had most desirable SCA effects for seed yield plant ${ }^{-1}$.
\end{abstract}

Keywards: Sesame (Sesamum indicum L.), Line $\times$ Tester analysis, Combining ability, Heterosis. 
In Egypt there is a big gap between production and consumption of vegetable oils. Sesame is one of the most important oilseed crops, which grown in many parts in the world. The total cultivated area of sesame in Egypt was about 82000 feddan in 2013 season, which produced 41328 ton, with an average seed yield of 0.504 ton/feddan (FAO, 2013).

One of the problems of sesame production in Egypt is unstable the productivity of the cultivated varieties. So, the main objectives of many sesamebreeding programs are improvement of seed yield productivity and stability. Therefore, the best-adapted varieties are desirable as parents in crossing programs aiming to improve seed yield potentiality and other economic traits. Also, it is seemed importance of studying the genetic architecture of the important agronomic traits and estimating each of general (GCA) and specific combining ability (SCA). Combining ability analysis aimed to understand the nature and extent of types of gene action in the inheritance of yield and its components for obtaining better recombination. Sumathi \& Kalaimani (2000), Manivannan \& Ganesan (2001), Kumar et al. (2004), Attia et al. (2004), Vidhyavathi et al. (2005), Kumar et al. (2006), Gwade et al. (2007), El-Shkhess \& Khalifa (2007), El-Shakhess et al.(2009), Abdelaziz et al. (2010) and Sedeck $\&$ Shafie (2013), found that the non-additive type of gene action was predominant for days to $50 \%$ flowering, number of branches plant $^{-1}$, number of capsules plant ${ }^{-1}$ and seed yield plant ${ }^{-1}$. On the other hand, many researchers (Hassaballa et al., 1996; Ramesh et al., 2000; Devasena et al., 2001; Manivannan \& Ganesan, 2001; Nijagum et al., 2002; Sarvanan \& Nadarajan, 2003; Donghwi et al., 2006; Banerjee \& Kole, 2009; El-Shakhess et al., 2009; Abdelaziz et al., 2010 and Sedeck \& Shafie, 2013) indicated that the importance of additive and non-additive gene action for all the studied traits. But, the additive gene effects were greater than non-additive gene effects for days to 50 $\%$ flowering, plant height, number of branches plant ${ }^{-1}$, number of capsules plant ${ }^{-1}$ and seed yield plant ${ }^{-1}$. Heterosis is considered as one of the most important tools that provide important information for improving seed yield and its components traits in sesame. The purposes of this research work were to study the combing ability and effects of heterosis for yield and its attributes via Line $\times$ Tester analysis.

\section{Material and Methods}

The current research work was done at Research Farm of Shandaweel Agricultural Research Station, Sohag, Egypt, during 2012, 2013 and 2014 summer seasons to study heterosis and combining ability of seed yield and its components in sesame. The materials used in this work were seven lines viz., $\left(\mathrm{L}_{1}\right)$ line N. A. 372, $\left(\mathrm{L}_{2}\right)$ local 166, $\left(\mathrm{L}_{3}\right)$ local 176, $\left(\mathrm{L}_{4}\right)$ N. A. 96, $\left(\mathrm{L}_{5}\right)$ H. 68 Family 21, $\left(\mathrm{L}_{6}\right)$ H.88 Family 17 and $\left(\mathrm{L}_{7}\right)$ N. A. 652 and four testers viz., $\left(\mathrm{T}_{1}\right)$ Giza 32, $\left(\mathrm{T}_{2}\right)$ line Sohag 1, $\left(\mathrm{T}_{3}\right)$ Shandaweel 3 and $\left(\mathrm{T}_{4}\right)$ line Shandaweel 2000, that vary in agronomic and morphological traits were selected for this study . The pedigree and origin of these genotypes is shown in Table 1.

Egypt. J. Agron. 37, No.2 (2015) 
TABLE 1. The Pedigree and origin of the used genotypes.

\begin{tabular}{|c|c|c|c|}
\hline No. & $\begin{array}{l}\text { Line and } \\
\text { Tester }\end{array}$ & Origin & Pedigree \\
\hline Line 1 & N. A. 372 & U.S.A & Unknown \\
\hline Line 2 & local 166 & Egypt 1981 & Unknown \\
\hline Line 3 & local 176 & Egypt & Unknown \\
\hline Line 4 & N. A. 96 & FAO & Unknown \\
\hline Line 5 & H. 68 Family 21 & Egypt & A line selected from line B $21 \mathrm{x}$ line 574 \\
\hline Line 6 & H.88 Family 17 & Egypt & A line selected from line B $21 \times$ line 574 \\
\hline Line 7 & N. A. 652 & U.S.A & Unknown \\
\hline Tester 1 & Giza 32 & Egypt 1986 & Local variety A line selected from Giza white x type 9 \\
\hline Tester 2 & Sohag 1 & Egypt & A line selected from Bengalian x Giza 32 \\
\hline Tester 3 & Shandaweel 3 & Egypt 1987 & A line selected from Giza 32 x N. A. 130 \\
\hline Tester 4 & Shandaweel 2000 & Egypt & A line selected from N.A.413 x AN.A.777 \\
\hline
\end{tabular}

A Line $\times$ Tester fashion was done using the seven lines and the four testers in 2012 summer season. The resulting 28 top crosses and their 11 parents were evaluated during the two summer growing seasons 2013 and 2014 in randomized complete block design with three replications. Each entry was sown in single row; 4 meters long, $50 \mathrm{~cm}$ width and the hills within row were spaced $20 \mathrm{~cm}$ apart with one plant left per hill after thinning. The cultural practices were applied according to the recommendations. Surface irrigation system was used in the experimental site. Some soil properties of the experimental site are shown in Table 2.

TABLE 2. Some soil properties of the experimental site (average the three growing seasons).

\begin{tabular}{|c|c|c|c|c|c|c|}
\hline $\begin{array}{c}\text { Sand } \\
(\%)\end{array}$ & Silt (\%) & (\%) Clay & Soil texture & $\begin{array}{c}\text { PH } \\
(1: 1)\end{array}$ & $\begin{array}{c}\text { Organic } \\
\text { matter }\end{array}$ & $\begin{array}{c}E C \\
\left(d_{s} ~ m^{-1}\right)\end{array}$ \\
\hline 55.21 & 11.64 & 33.15 & Sandy clay & 7.50 & 1.89 & 0.37 \\
\hline
\end{tabular}

At harvest time, ten guarded plants from each entry were taken to record the following data on the traits;

1- Height of first capsule in $\mathrm{cm}$.

2- Plant height in $\mathrm{cm}$.

3- Length of fruiting zone in $\mathrm{cm}$.

4- Number of branches plant ${ }^{-1}$.

5- Number of capsules plant ${ }^{-1}$.

6- Capsule length in $\mathrm{cm}$.

7- 1000-seed weight in grams.

8- Seed yield plant ${ }^{-1}$ in grams.

9- Seed oil content as percentage. Oil was extracted by using petroleum ether $\left(60-80^{\circ} \mathrm{C}\right)$ and Soxhelt apparatus according to AOAC (1980).

Furthermore number of days from planting to flowering $50 \%$ of plants for each entry was recorded. Line $\times$ tester analysis was performed according to Steel $\&$ Torrie (1980). Combining ability effects were computed by the Line $\times$ tester method according to Singh \& Chaudhary (1985). In this analysis, the parents mean squares are considered estimates of general combining ability (GCA), 
while the mean squares of male $\times$ female interactions provides an estimate of specific combining ability (SCA). Heterosis expressed as percentage was calculated as the deviation of $\mathrm{F}_{1}$ means from the better parent (BP), as described by Bhatt (1971) as follow:

$$
\mathrm{H}(\%)=\frac{F 1-B P}{B P} \times 100
$$

The significant of heterosis effect was tested by LSD test.

\section{Results and Discussion}

Analysis of variance

The combined analyses of variance for studied traits over two years are listed in Table 3. Analysis of variance revealed high significant mean squares due to genotypes and years for all studied traits except 1000 -seed weight and oil percentage for years. The interaction of genotypes $\times$ years recorded highly significant differences for all the studied traits, except for days to flowering, number of branches plant ${ }^{-1}$ and1000-seed weight which were insignificant. This indicates that different of environmental conditions during both years. Furthermore, results of line $\times$ tester analysis showed high significant variances among crosses and lines for all of the studied traits over years (Table 3). The testers showed significant variances for all traits, except for 1000-seed weight. The results indicated that, mean sum of squares due to Line $\times$ tester interaction were highly significant for all studied traits over two years. Significant and Highly significant variances were observed for crosses $\mathrm{x}$ year and tester $\times$ year interactions for most studied traits. Meanwhile, variances due to line $\times$ year $(\mathrm{L} \times$ $\mathrm{Y})$ and line $\mathrm{x}$ tester $\times$ year $(\mathrm{L} \times \mathrm{T} \times \mathrm{Y})$ interactions were highly significant for days to $50 \%$ flowering, plant height, oil percentage and seed yield plant ${ }^{-1}$ for (L $\times \mathrm{Y})$ and for days to $50 \%$ flowering, height of the first capsule and seed oil content $\%$ only for $(\mathrm{L} \times \mathrm{T} \times \mathrm{Y})$. These results indicated that the studied crosses had different ranking from year to another. In addition, it indicated that importance of evaluation the crosses at many environments, especially for seed yield. These results showed also great diversity for both lines and testers in seed yield, which contributed to the performance of their respective crosses. These results are in the line with those obtained by Manivannan \& Ganesan (2001), Kar et al. (2002), Sanker \& Kumar (2003), Kumar et al. (2004), Vidhyauvathi et al. (2005), Taher \& El-Samanody (2006), El-Shakhess et al. (2007), Banerjee \& Kole (2009), El-Shakhess et al. (2009), Abdelaziz et al. (2010) and Sedeck \& Shafei (2013).

\section{Mean performance}

The combined data over the two years for the studied traits are presented in Table 4. Number of days to $50 \%$ flowering ranged from 44.83 (N.A.372) to 56.33 (Local166) with an average of 75.50 days among the parental lines. While, among the crosses, it varied from 42.00 (Giza32 $\times$ Local 166) to 52.17 (Shandaweel $3 \times$ N.A.96) with an average of 47.08 days. In general out of the crosses, six were earlier than their earlier parents and sixteen were significantly

Egypt. J. Agron . 37, No.2 (2015) 


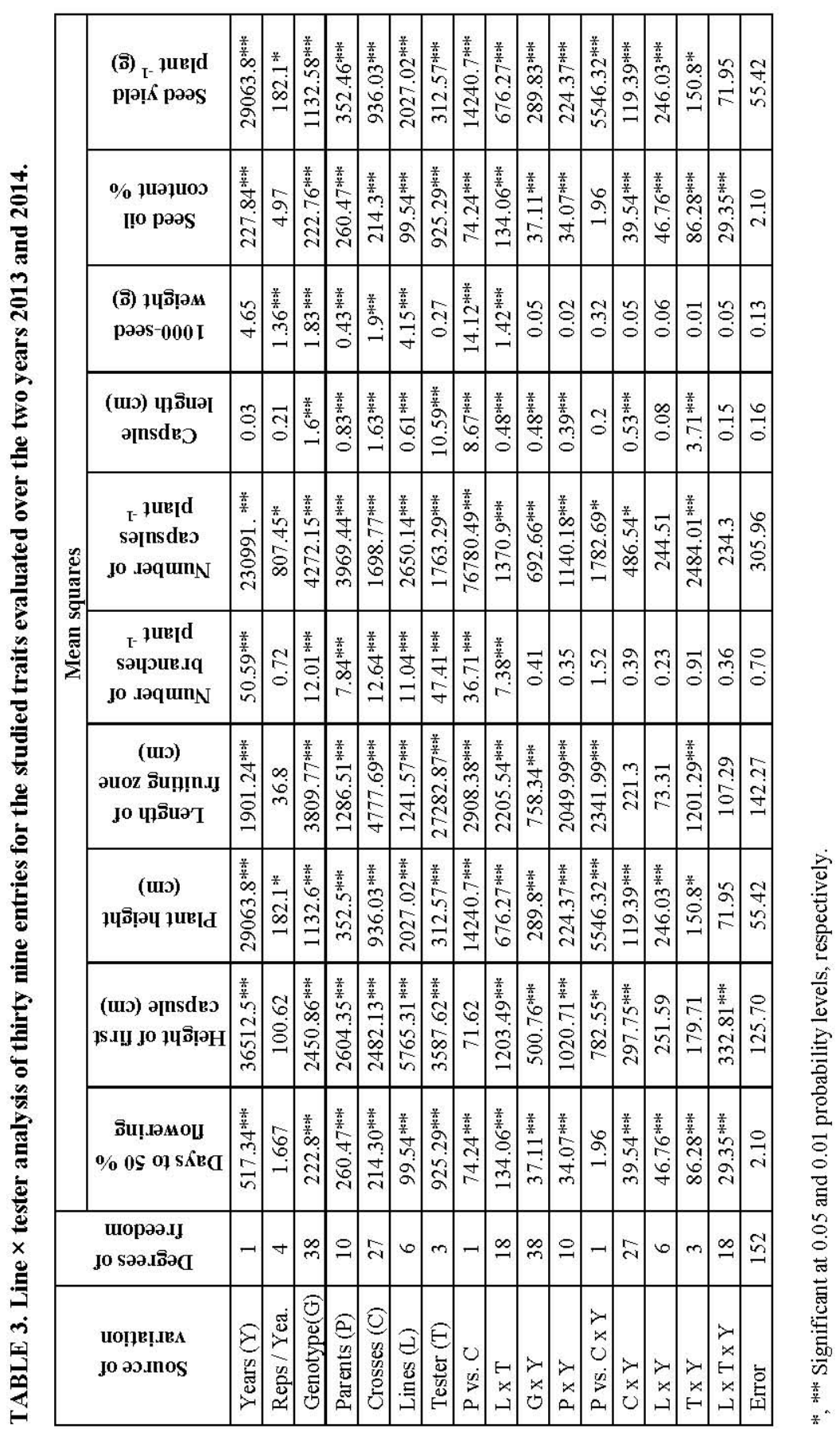




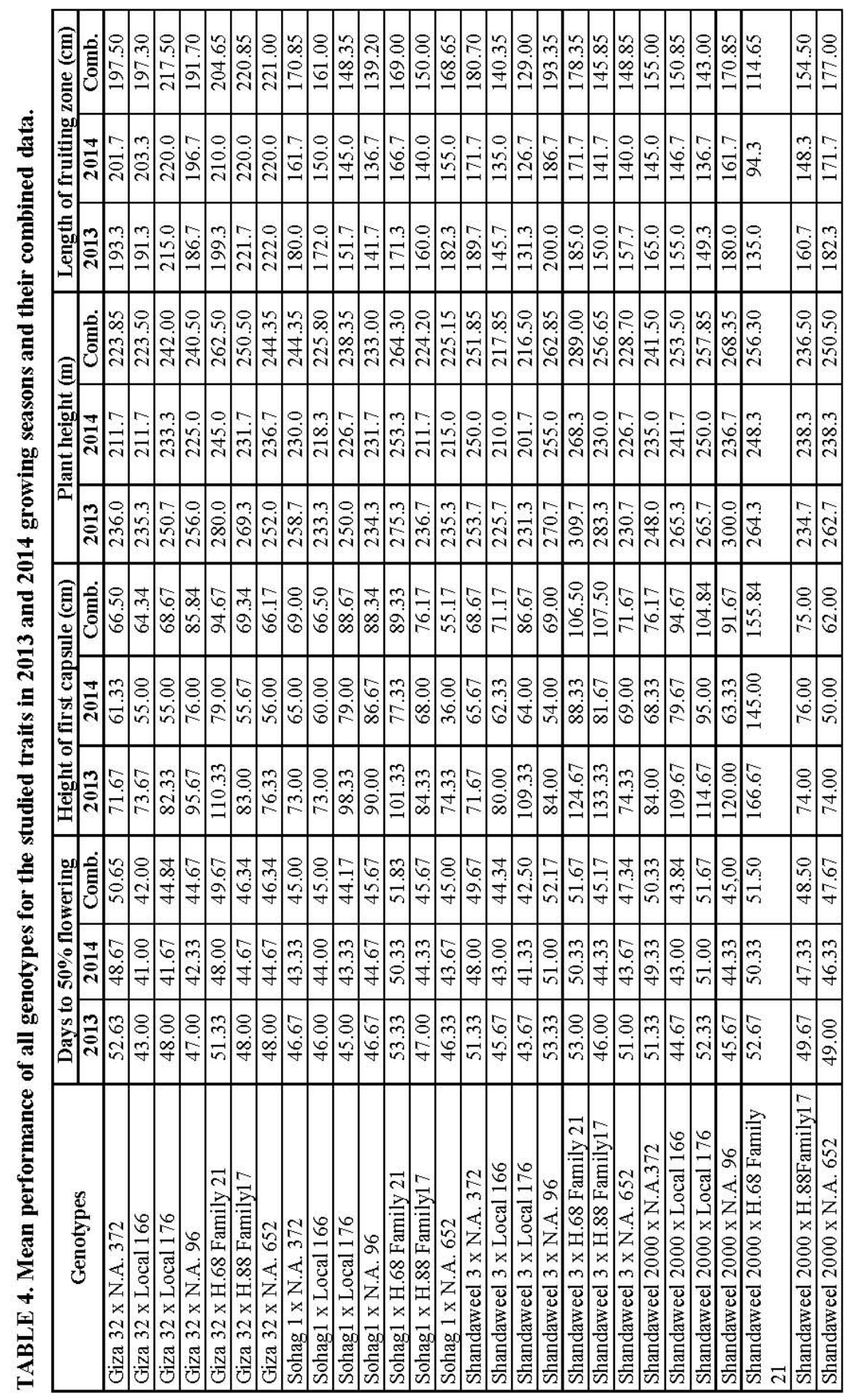

Egypt. J. Agron . 37, No.2 (2015) 


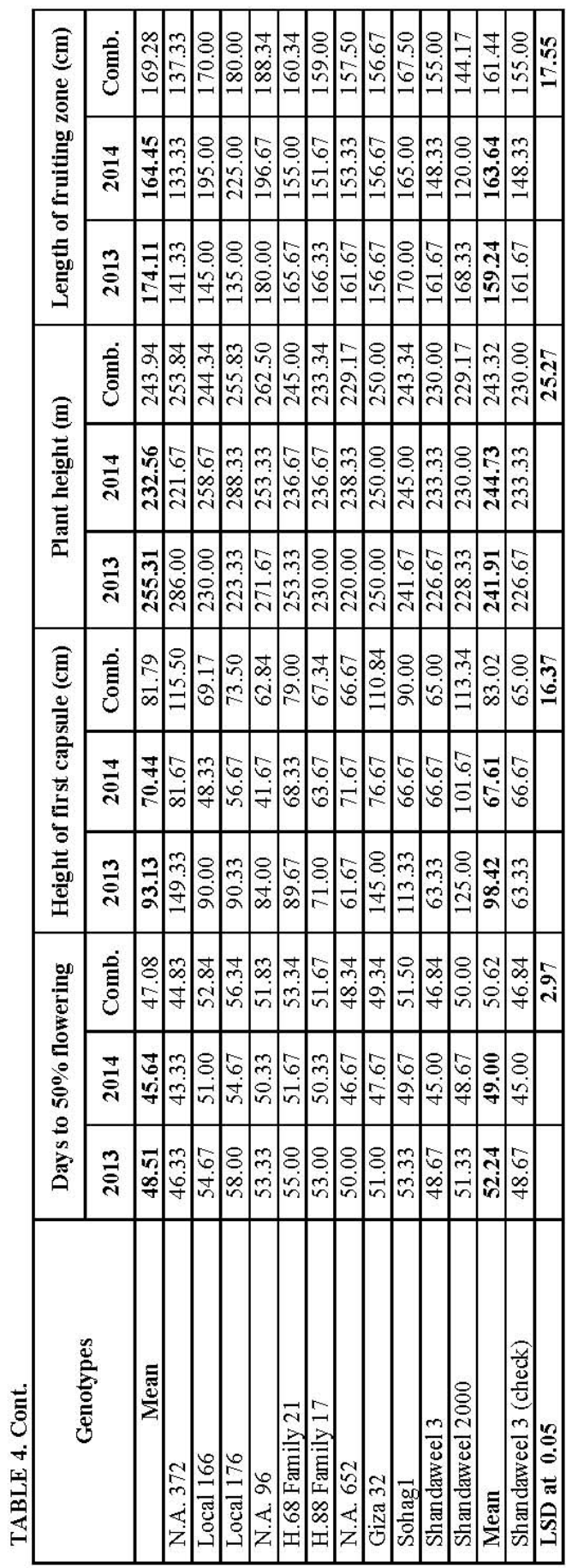

Egypt. J. Agron . 37, No. 2 (2015) 


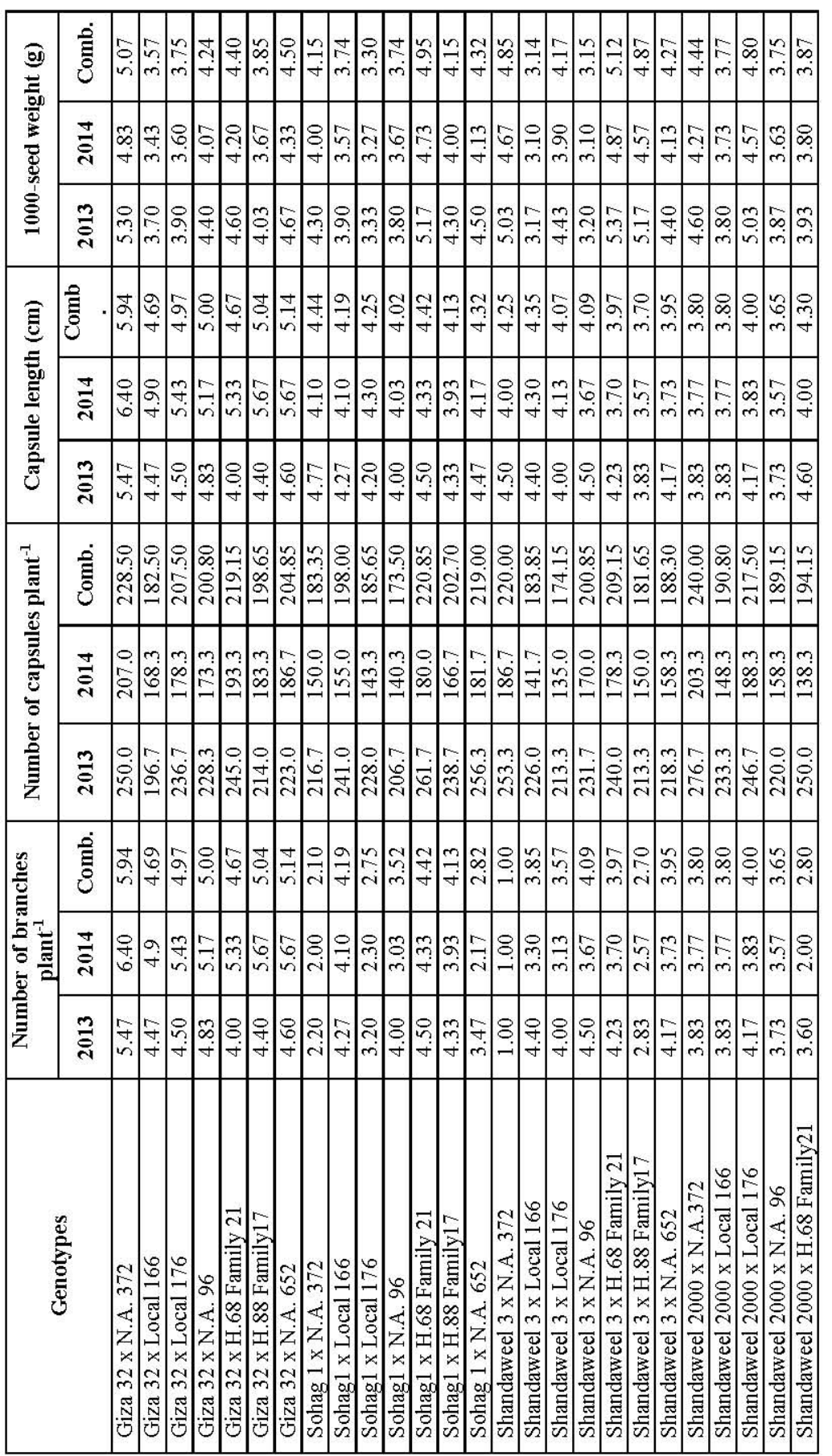

Egypt. J. Agron . 37, No.2 (2015) 
LINE $\times$ TESTER ANALYSIS FOR YIELD ...

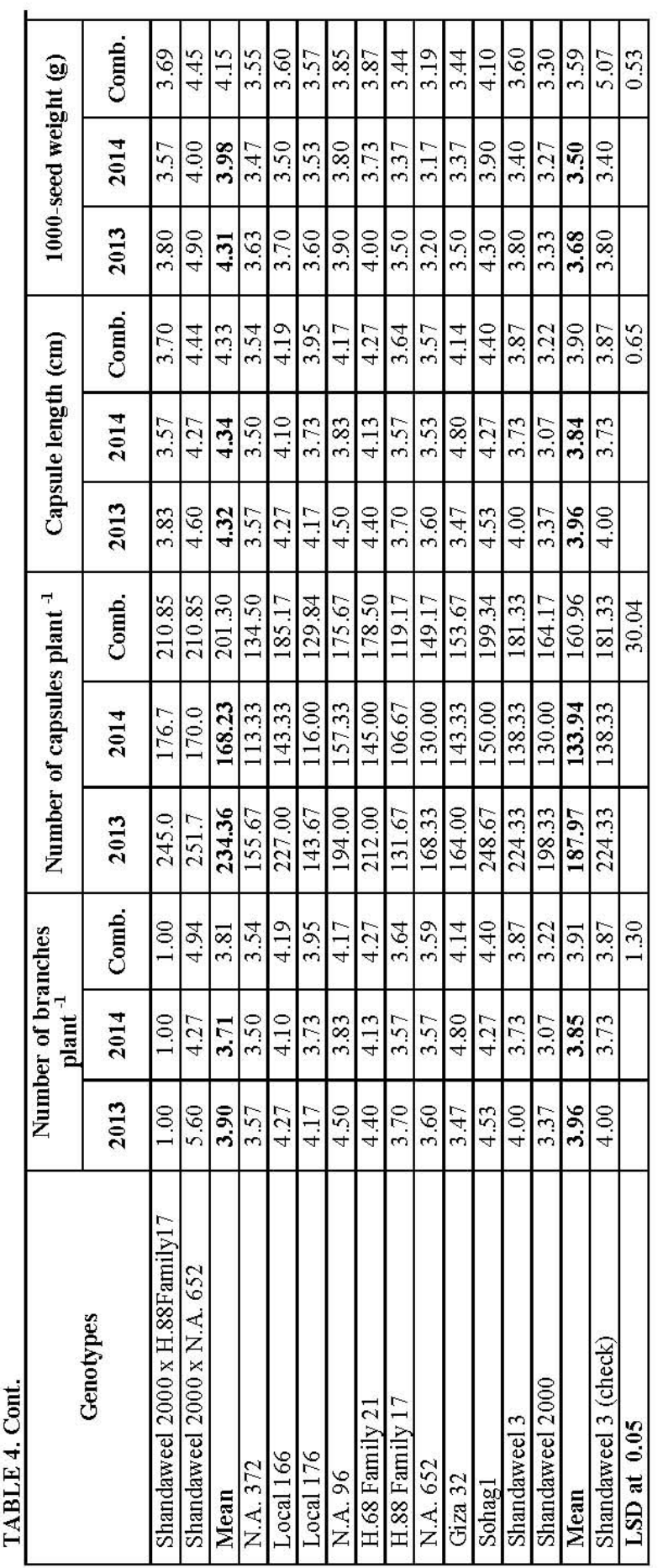

Egypt. J. Agron. 37, No. 2 (2015) 


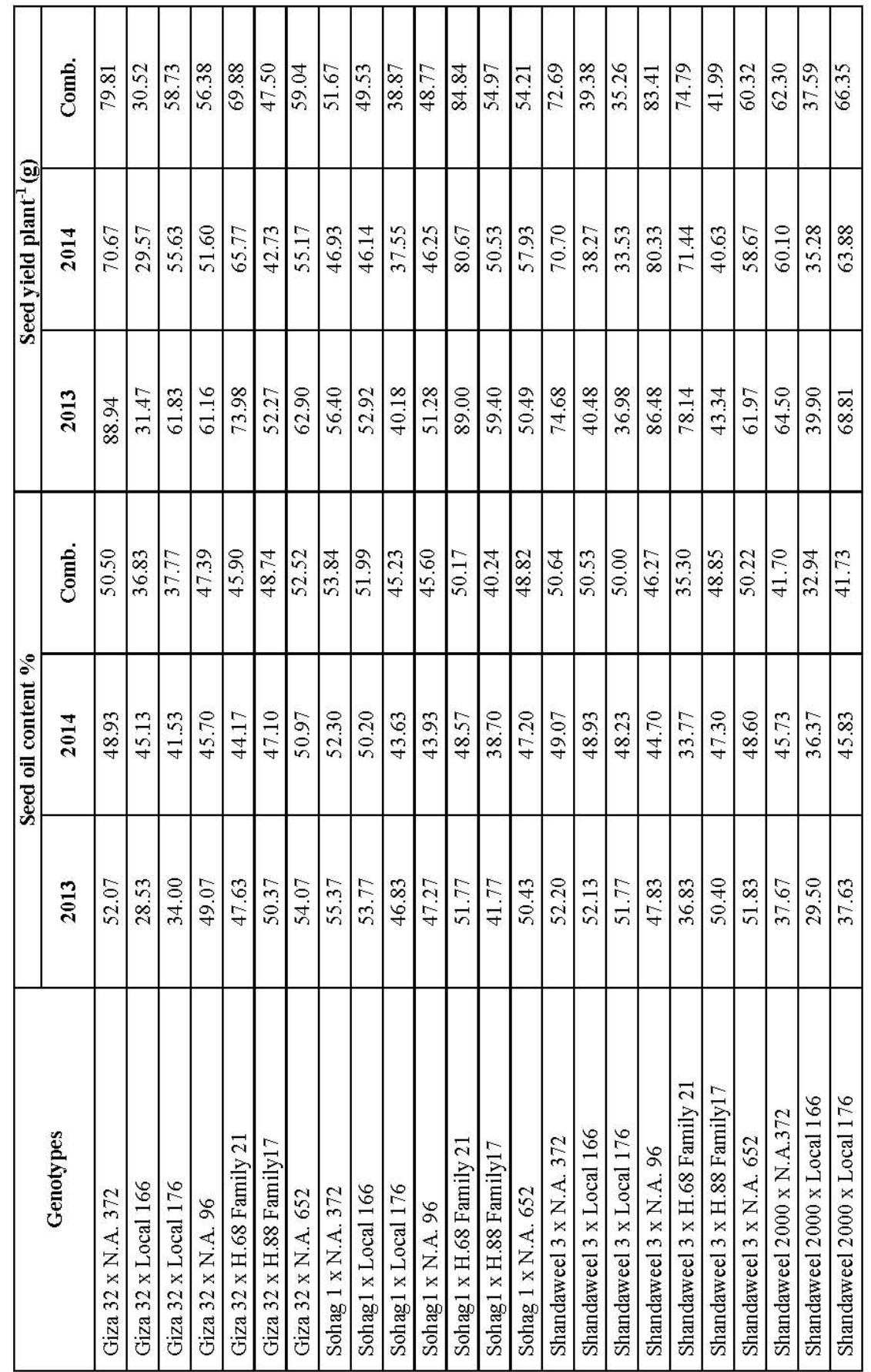

Egypt. J. Agron . 37, No.2 (2015) 


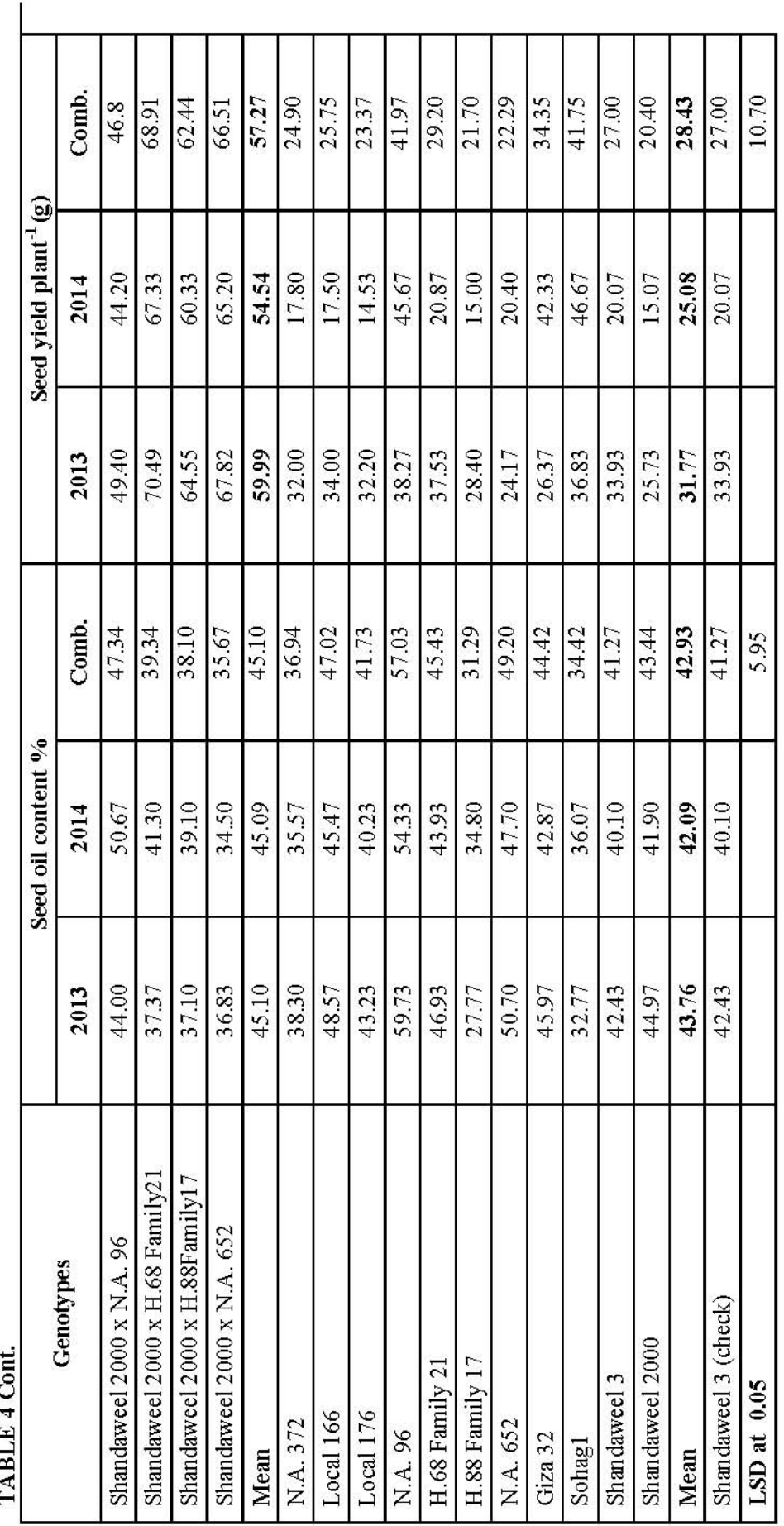

Egypt. J. Agron . 37, No. 2 (2015) 
earlier compare to the check variety. Concerning height of the first capsule, the measurements of parental lines ranged from $62.83 \mathrm{~cm}$ (N.A.96) to 115.50 (N.A.372) with an average of $83.01 \mathrm{~cm}$. Moreover, among the crosses the values varied from 62.00 (Shandaweel $2000 \times$ N.A.652) to 155.83 (Shandaweel $2000 \mathrm{x}$ H.68 Family 21) with an average of $81.79 \mathrm{~cm}$. The results also indicate that the values of plant height ranged among the lines from 227.50 (Shandaweel 3) to 264.17 (Giza 32 and Sohag1) with an average of $264.71 \mathrm{~cm}$, while varied from 216.50 (Shandaweel $3 \times$ Local 176) to 289.00 (Shandaweel $3 \times$ H.68 Family 21) with an average of $243.94 \mathrm{~cm}$ among the crosses. In addition, most of the crosses show superiority in plant height compared to their parents and the check variety. Regarding length of fruiting zone, the combined performance of parental lines ranged from 144.17 (Shandaweel 2000) to 188.33 (N.A.96) with an average of $161.44 \mathrm{~cm}$. While, it varied from 114.67 (Shandaweel $2000 \times$ H.88 Family 17) to 221.00 (Giza $32 \times$ N.A.652) with an average of $170.75 \mathrm{~cm}$ among the crosses. Performance of the parental lines and the crosses for number of branches plant ${ }^{-1}$ indicate that, the measurements ranged from 1.00 (N.A. 652) to 4.25 (H.88 Family 17) with an average of 3.11 , and from 1.00 (Shandaweel $3 \times$ N.A.372 and Shandaweel $2000 \times$ H8 Family 1.87$)$ to $5.94($ Giza32 $\times$ N.A.652) with an average of 3.80 , respectively. The cross Shandaweel $2000 \times$ N.A. 372 gave the highest number of capsules plant ${ }^{-1}$ (240.0) compared to the parents and the check. Results of capsule length indicate that the cross Giza $32 \times$ N.A.372 was the longest one (5.93) compared their parental lines and check (4.27 and 3.87), respectively. The combined data for 1000 -seed weight revealed that, the values of parental lines ranged from 3.18 (N.A.652) to 4.10 (Sohag1) with an average of 3.60. Likewise, the crosses had values ranged from 3.13 (Shandaweel $3 \times$ Local 166) to 5.12 (Shandaweel $3 \times$ H 68 Family 21) with an average of 4.14.

Results of seed oil content percentage over two years indicated that, the values of parental lines ranged from 31.28 (H.88 Family 17) to 53.70 (N.A.96) with an average of 42.92. Moreover, the performance of crosses varied from 32.67 (Shandaweel $2000 \times$ Local 166) to 51.18 (Sohag $1 \times$ N.A. 372) with an average of 45.58. Results also revealed that, the parental line N. A. 96 had the highest seed oil content $(53.70 \%)$ compared to all genotypes. However, the maximum value among crosses was obtained by the cross Sohag $\times$ N. A. 372 $(51.18 \%)$. Results of seed yield plant $^{-1}$ over two years indicate that, the performance of parental lines ranged from 20.40 (Shandaweel 2000) to 41.97 (N.A.96) with an average of $28.43 \mathrm{~g}$, while from 30.52 (Giza $32 \times$ Local 166) to 84.84 (Sohag $1 \times$ H. 68 Family 21 ) with an average of $57.33 \mathrm{~g}$ among the crosses. There were these crosses that had significant heaviest seed yield compared to their parents over two years, reflecting the presence of hybrid vigor. Generally, the best crosses (Giza $32 \times$ N.A. 372$)$, $($ Sohag $1 \times$ H. 68 Family 21 ) and (Shandaweel $3 \times$ N.A. 96) were the best, whereas, they gave the maximum yield over the two years. Furthermore, these crosses are also significantly outyielded the check variety. So, it could be put these best crosses into evaluation trails in wide scale and could be considered as promising crosses. Also, out of the testers, Sohag 1 was the best and can be used in crossing with more female lines. These results are agreement with those obtained by Shabana Egypt. J. Agron . 37, No.2 (2015) 
et al. (1996), EL-Ahmar et al. (1996), Manivannan \& Ganesan (2001), Kar et al. (2002), Sanker \& Kumar (2003), Kumar et al. (2004), Vidhyavathi et al. (2005), Taher \& El-Samanody (2006), El-Shakhess (2007), Banerjee \& Kole (2009). ElShakhess et al. (2009), Abdelaziz et al. (2010) and Sedeck \&Shafie (2013).

\section{Heterosis effects}

Estimates of heterosis over better parent are listed in Table 5. Heterosis of days to $50 \%$ flowering over the two years ranged from 0.40 to $-14.90 \%$. Fifteen crosses exhibited a highly significant negative deviation from better parent. The crosses Giza $32 \times$ Local 166, Sohag $1 \times$ Local 166 and Sohag1 × Local 176 showed maximum desirable heterotic effects for earliness. Range of heterosis for height of the first capsule was 3.00 to $-40.00 \%$. Crosses Shandaweel $3 \times \mathrm{H}$. 68 Family 21 and Shandaweel $3 \times$ H. 88 Family 17 showed positive and highly significant heterosis for plant height and recorded the maximum values over the better parent. It is worthy to mention that in sesame, crossing two inbred line could be accompanied by positive heterosis in resulting crosses. Thus, in this case crosses would be always taller than their parent inbred lines.

Nine crosses showed a significant negative heterosis relative to the better parent for fruiting zone. The crosses Giza $32 \times$ N.A. 372, Giza $32 \times$ Local 176 , Giza $32 \times$ H.88 Family17, Giza $32 \times$ Local 176 and Giza $32 \times$ N.A. 652 recorded the maximum heterosis values compared their better parent. These results indicate that Giza 32 contained the favorable genes for this trait. Thus, it could be involved in any breeding program for improvement this trait. Thirteen crosses revealed highly significant positive heterosis compared to the better parent for number of branches plant ${ }^{-1}$. The crosses Giza $32 \times$ N.A.652, Giza $32 \times$ H.68 Family 21 and Shandaweel $3 \times$ N.A. 652 gave the highest desirable heterotic effect.

Results revealed that sixteen crosses showed positive and significant heterosis relative to better parent for number of capsules plant ${ }^{-1}$. Crosses Giza 32 $\times$ N.A. 372 , Giza $32 \times$ Local 176, Giza $32 \times$ N.A.652, Shandaweel $2000 \times$ N.A.372 and Shandaweel $2000 \times$ Local 176 had the maximum desirable heterotic effects. Positive and significant heterosis over the better parent were shown in seven crosses for capsule length. Crosses Giza $32 \times$ N.A. 372 and Shandaweel $2000 \times$ N.A. 652 showed the highest heterotic effect for capsule length. The range of heterosis for 1000 -seed weight was -19.51 to $0.00 \%$. Positive and significant heterosis was obtained by eighteen crosses for this trait. The three crosses Giza $32 \times$ N.A.372, Shandaweel $2000 \times$ Local 176 and Shandaweel $2000 \times$ N.A.652 gave the maximum desirable heterotic effect for this trait. With respect to seed oil content percentage, values of heterosis ranged from 0.92 to -30.59 . Six crosses showed positive and significant heterosis. Crosses Sohag $1 \times$ N.A.372 and Shandaweel $3 \times$ N.A. 372 had the highest heterotic effect for seed oil content percentage. The range of heterosis over better parent for seed yield plant $^{-1}$ varied from 18.52 to $237.80 \%$. All crosses except 


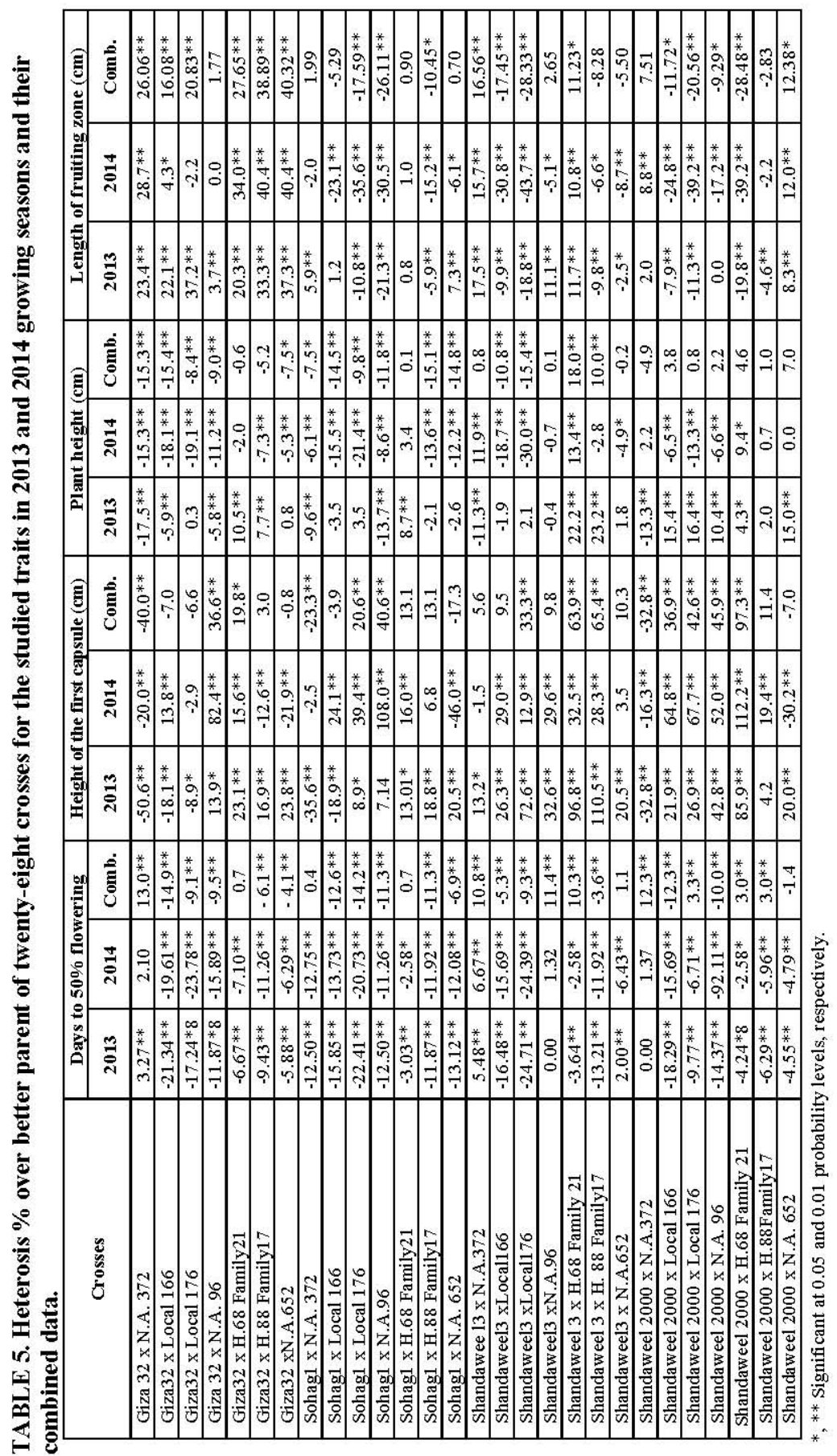

Egypt. J. Agron . 37, No.2 (2015) 


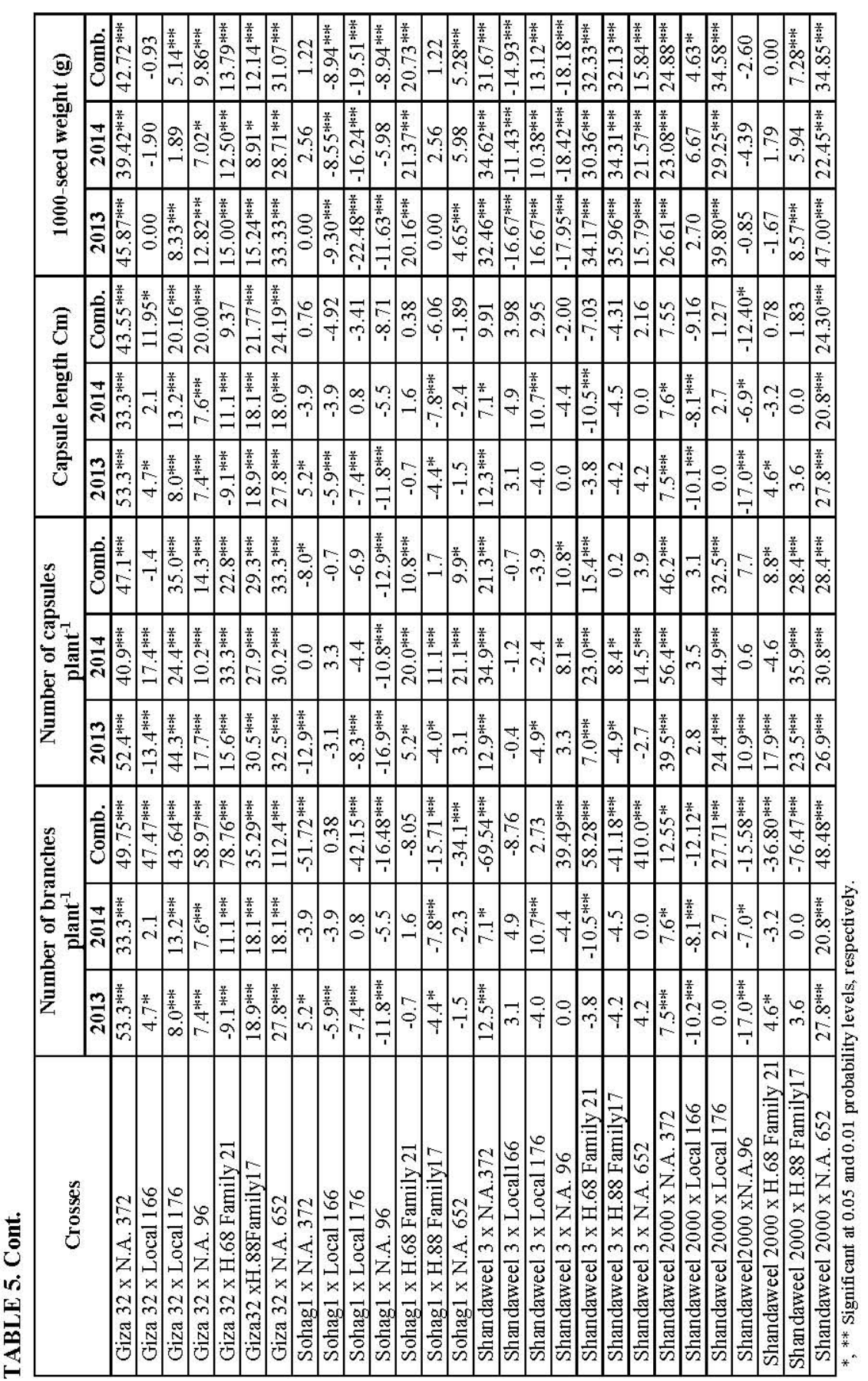

Egypt. J. Agron . 37, №. 2 (2015) 


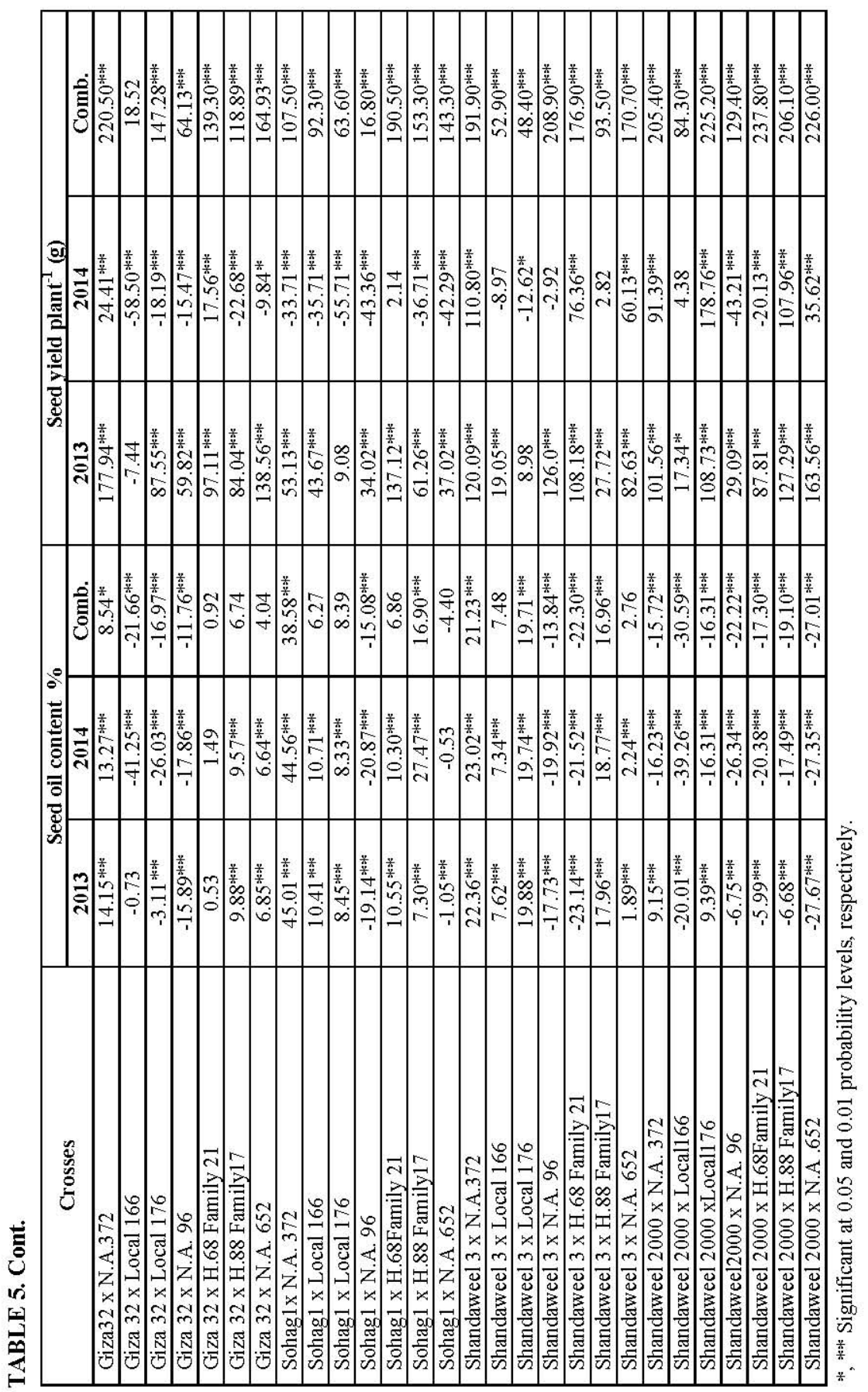

Egypt. J. Agron . 37, №.2 (2015) 
one cross only showed highly significant positive heterosis. The four crosses Giza $32 \times$ N.A. 372, Shandaweel $2000 \times$ Local 176, Shandaweel $2000 \times$ H.68 Family 21 and Shandaweel $2000 \times$ N.A.652 had the maximum desirable heterotic effect. In general, the four crosses Giza32 $\times$ N.A.372, Shandaweel 2000 $\times$ Local 176, Shandaweel $2000 \times$ H. 68 Family 21 and Shandaweel $2000 \times$ N.A.652 were found to be the heaviest in most of the studied traits compared to their better parents. These results are agreement with those obtained by Shabana et al. (1996), EL-Ahmar et al. (1996), Mishra \& Sikarwar (2001), Krishna et al. (2002), El-Shakhess (2003), Uzun et al. (2004), El-Shakhess \& Khalifa (2007), El-Shakhess et al. (2009), Abdelaziz et al. (2010) and Sedeck \& Shafie (2013).

\section{Combining ability}

Concerning the variances of GCA and SCA, it is known according to Line $\times$ tester method that variance of females and males considered equivalent to GCA (additive) and variance of females $\times$ males considered equivalent to SCA (non additive). The analysis of variance pointed out that contributors of crosses (females, males and females $\times$ males) were highly significant or significant for most studied traits in both seasons. Data belonging to partitioning sum of squares of crosses to their attributers (females, males and females $\times$ males) for the studied traits showed that; for days to $50 \%$ flowering, accounted GCA as calculated from the parents were 31.11 and $4.01 \%$ and 29.84 and 4.46 , while SCA as accounted from female $\times$ male interaction reached 0.12 and $0.28 \%$ in both seasons, respectively, while the SCA reached 3.08 and 3.12 in both seasons, respectively. Regarding height of the first capsule, GCA accounted for 32.27 and $24.82 \%$ and 11.06 and $7.87 \%$, while SCA reached 7.54 and $10.59 \%$ in both seasons, respectively. Concerning plant height accounted GCA were 31.84 and $2.96 \%$ and 40.99 and $6.85 \%$, while SCA recorded 1.37 and $2.53 \%$ in both seasons, respectively. For length of fruiting zone accounted GCA were 9.34 and $0.67 \%$ and 23.14 and $4.09 \%$, while SCA estimated 0.90 and 0.54 in both seasons, respectively. With regard to number of branches per plant GCA accounted for 11.57 and $10.99 \%$ and 12.37 and $11.84 \%$, while SCA reached 0.11 and $0.18 \%$ in both seasons, respectively. For number of capsules plant ${ }^{-1}$ GCA accounted for 83.82 and $42.95 \%$ and 20.69 and $2.04 \%$, while SCA recorded 29.77 and $26.12 \%$ in both seasons, respectively. With respect to capsule length GCA accounted for 24.29 and $22.48 \%$ and 2.70 and $10.60 \%$, while SCA reached 2.33 and $0.58 \%$ in both seasons, respectively. Concerning 1000 seed weight accounted GCA were 3.92 and $5.04 \%$ and 4.09 and 3.51\%, while SCA estimated 0.19 and $0.29 \%$ in both seasons, respectively. For seed oil content \% GCA accounted for 36.18 and $6.46 \%$ and 43.80 and $4.09 \%$, while SCA reached 1.85 and $4.71 \%$ in both seasons, respectively. With regard to seed yield plant ${ }^{-1}$ accounted GCA as also calculated from the parents were 2.23 and $1.38 \%$ and 24.59 and $26.04 \%$, while SCA as also accounted from female $\times$ male interaction reached 0.12 and $0.28 \%$ in both seasons, respectively. The previous results proved that both additive and non additive gene actions controlled most studied traits and the additive gene action played the major role in the inheritance of these traits. 


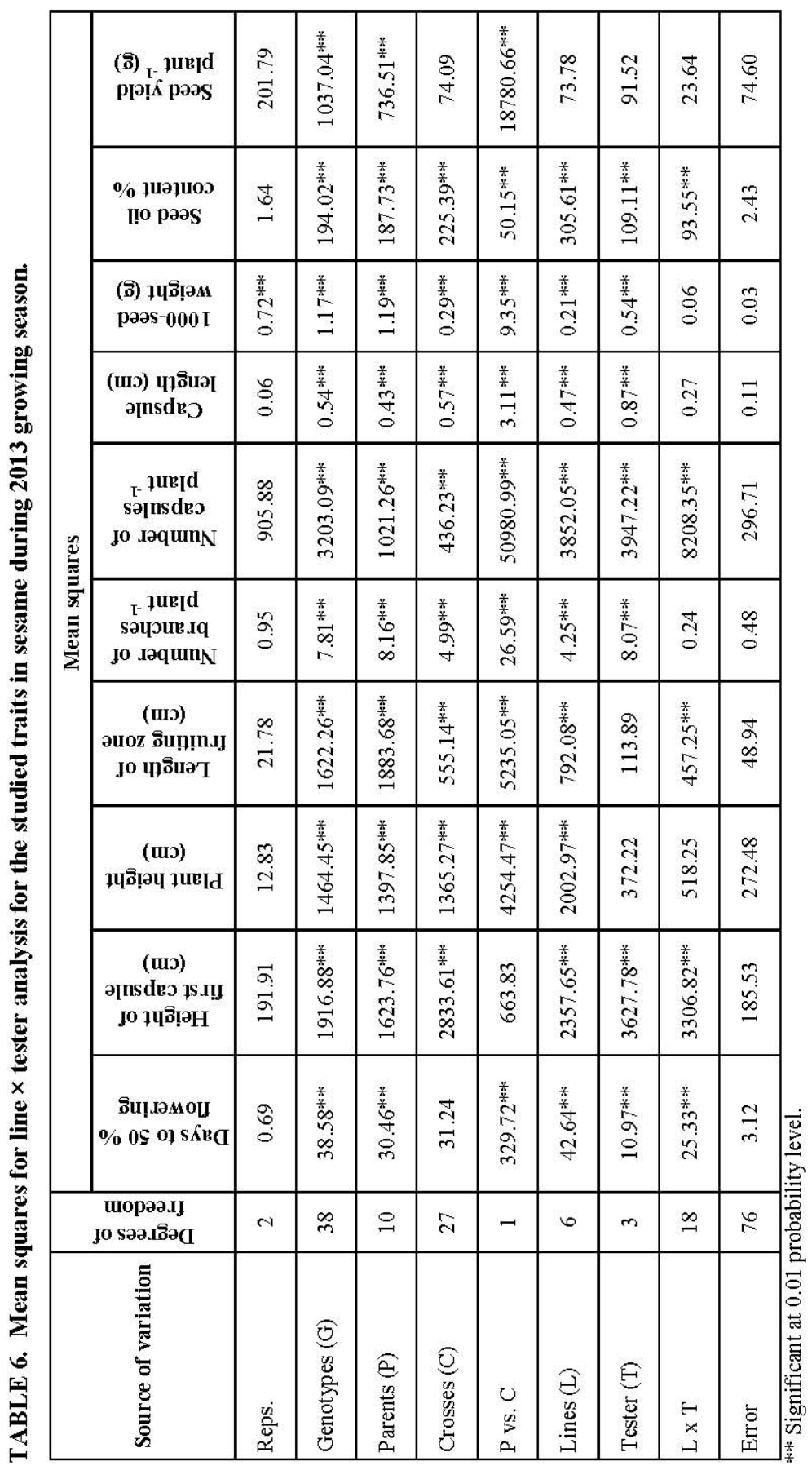

Egypt. J. Agron . 37, No.2 (2015) 


\begin{tabular}{|c|c|c|c|c|c|c|c|c|c|c|}
\hline \multirow{10}{*}{ 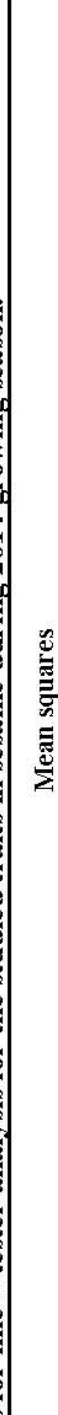 } & 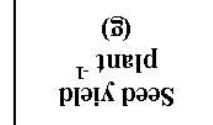 & & $\begin{array}{l}\frac{1}{*} \\
\infty \\
\infty \\
\infty \\
\infty\end{array}$ & $\begin{array}{l}\frac{v}{\frac{5}{4}} \\
\bar{\sigma} \\
\infty \\
\frac{\infty}{m}\end{array}$ & 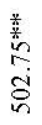 & 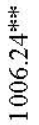 & 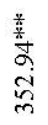 & 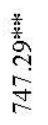 & 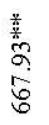 & đ্ं \\
\hline & 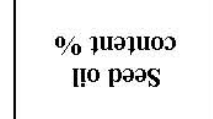 & $\stackrel{2}{3}$ & 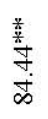 & 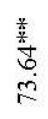 & 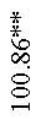 & 旁 & 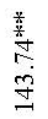 & 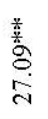 & $\begin{array}{l}\frac{1}{4} \\
\stackrel{8}{8} \\
\dot{0}\end{array}$ & $\stackrel{\text { ?ี }}{\circ}$ \\
\hline & 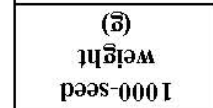 & 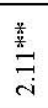 & $\stackrel{\stackrel{*}{*}}{\stackrel{*}{*}}$ & $\begin{array}{l}\frac{.}{* 0} \\
\stackrel{0}{0} \\
0\end{array}$ & $\stackrel{0}{:}$ & 辠 & $\stackrel{ \pm}{:}$ & $\stackrel{\sim}{\circ}$ & $\stackrel{\Xi}{\circ}$ & ণึ \\
\hline & 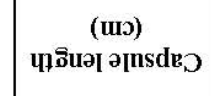 & ?ొ & 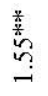 & $\stackrel{\stackrel{*}{*}}{\stackrel{m}{m}}$ & $\begin{array}{l}\stackrel{*}{*} \\
\stackrel{4}{6} \\
\stackrel{0}{0}\end{array}$ & 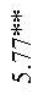 & $\overrightarrow{\mathrm{o}}$ & 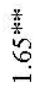 & તે & ন্ \\
\hline & 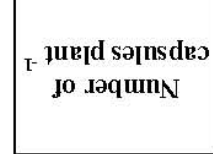 & $\stackrel{\leftrightarrow}{\circ}$ & 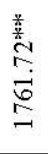 & 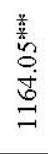 & $\begin{array}{l}\text { \%̆ } \\
\text { ले } \\
\stackrel{\sigma}{r}\end{array}$ & 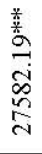 & $\begin{array}{l}\frac{1}{6} \\
\dot{8} \\
\infty \\
\infty \\
\infty \\
0 \\
0\end{array}$ & $\underset{\overrightarrow{2}}{\stackrel{2}{\overrightarrow{2}}}$ & $\begin{array}{l}2 \\
2 \\
2 \\
2\end{array}$ & $\begin{array}{l}\stackrel{\infty}{\circ} \\
\stackrel{+}{m}\end{array}$ \\
\hline & 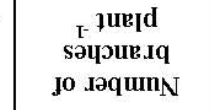 & 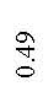 & $\frac{\frac{\vec{*}}{4}}{\stackrel{6}{+}}$ & 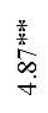 & $\frac{\stackrel{*}{*}}{\stackrel{m}{n}}$ & $\begin{array}{l}\frac{1}{6} \\
6 \\
6 \\
= \\
=\end{array}$ & $\stackrel{\stackrel{*}{*}}{\vec{i}}$ & $\frac{\stackrel{0}{*}}{\stackrel{5}{a}}$ & ণ্ণি & ̊̊ \\
\hline & 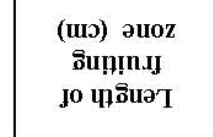 & $\frac{\infty}{n}$ & 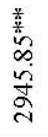 & 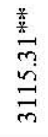 & 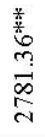 & $\begin{array}{l}\text { mै } \\
\text { nุ }\end{array}$ & 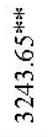 & 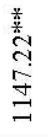 & 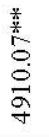 & 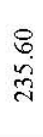 \\
\hline & 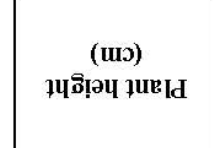 & $\begin{array}{l}\tilde{N} \\
\tilde{\sim}\end{array}$ & 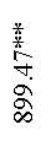 & 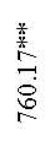 & 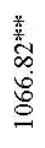 & 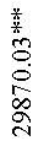 & 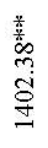 & $\begin{array}{l}2 \\
\infty \\
\infty \\
\dot{\sigma}\end{array}$ & $\frac{\sigma}{6}$ & 离 \\
\hline & 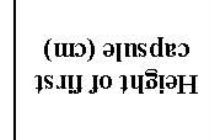 & $\stackrel{m}{\sigma}$ & 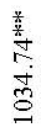 & 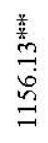 & 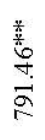 & 啇 & $\begin{array}{l}\frac{1}{3} \\
0 \\
0 \\
2 \\
0 \\
0\end{array}$ & 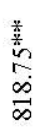 & 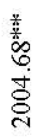 & $\begin{array}{l}n \\
\infty \\
0 \\
0\end{array}$ \\
\hline & 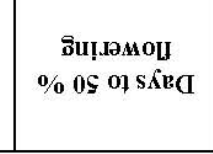 & \begin{tabular}{l}
\multirow{b}{*}{} \\
i
\end{tabular} & $\begin{array}{l}\frac{1}{0} \\
0 \\
0 \\
0 \\
0 \\
0\end{array}$ & 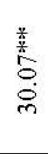 & 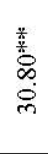 & 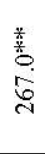 & 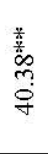 & $\stackrel{\infty}{\stackrel{\infty}{\mathrm{i}}}$ & 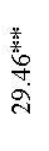 & 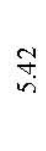 \\
\hline & 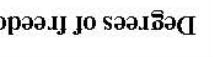 & $\mathrm{N}$ & $\infty$ & $\stackrel{-}{-}$ & $\widehat{\sim}$ & - & 6 & $m$ & $\stackrel{\infty}{-}$ & $\because 2$ \\
\hline & 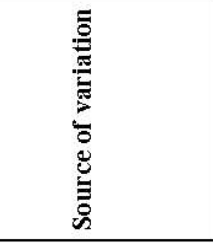 & 官 & 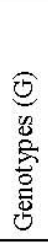 & 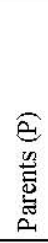 & $\begin{array}{l}0 \\
0 \\
0 \\
0 \\
0 \\
0 \\
0\end{array}$ & $\begin{array}{l}0 \\
\dot{i} \\
2 \\
\dot{2}\end{array}$ & 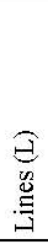 & 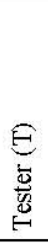 & 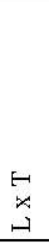 & 㟥 \\
\hline
\end{tabular}




\section{General combining ability (GCA) effects}

The general combining ability (GCA) effects of both female and male lines in 2013, 2014 seasons and their combined are listed in Table 8. Based on general combining ability (GCA) effects, the female lines Local 166 and Local 176 and the male parent Sohag1 were good general combiners for earliness, whereas they had negative GCA effects over the two years. Among the parents, the female line H.68 family 21 and the male parent Shandaweel 2000 had significant positive GCA effect in 2013 and 2014 seasons and their combined for height of the first capsule. Thus it could be considered these parental lines as a source of favor gene for shortness of the first capsule. The parents H.68 family 21 in 2013 and 2014 seasons and their combined and Shandaweel 2000 in 2013 season expressed significant positive GCA effects for plant height. So, it could be seemed a good general combiners for increasing plant height. In contrary, the male parent Local 166 was found to be good general combiners in two seasons and their combined for shortness.

For length of fruiting zone, the male parent Giza 32 was found to be good general combiners in two years and their combined. In contrast, significant negative and GCA effects for this trait were obtained by Shandaweel 2000 and Shandaweel 1 in the two seasons and their combined.

For number of branches plant ${ }^{-1}$, the female parent N.A.652 in two seasons 2013 and 2014 seasons and their combined and the male parent Giza32 in 2013 season had positive and significant GCA effects.

Results of number of capsules plant ${ }^{-1}$ showed that the female parent N.A. 372 had positive and significant GCA effect in 2013 and 2014 seasons and their combined, while, the female line Local166 had negative and significant GCA effects.

For capsule length, the GCA effect of parents revealed that the female line N.A. 372 in the first season only and the male parent Giza 32 in the two seasons and their combined had positive and significant values.

The results also indicated that the female lines N.A.372, H.68 family 21 in the two years and their combined, N.A. 652 in 2014 and the combined data and N.A. 96 in 2014 only gave positive and significant GCA effects for 1000-seed weight. Thus, it could be considered these parental lines as a source of genes for heavier 1000-seed weight.

Regarding seed oil content percentage, the GCA effects of parents showed that the female lines N.A. 372 and N.A. 96 in the two seasons and their combined and N.A. 652 in 2014 only had positive and highly significant values. In addition, the two parents Sohag1 and Shandaweel 1 in the two years and their combined and Giza 32 in 2014 only gave positive and highly significant values. 
LINE $\times$ TESTER ANALYSIS FOR YIELD ...

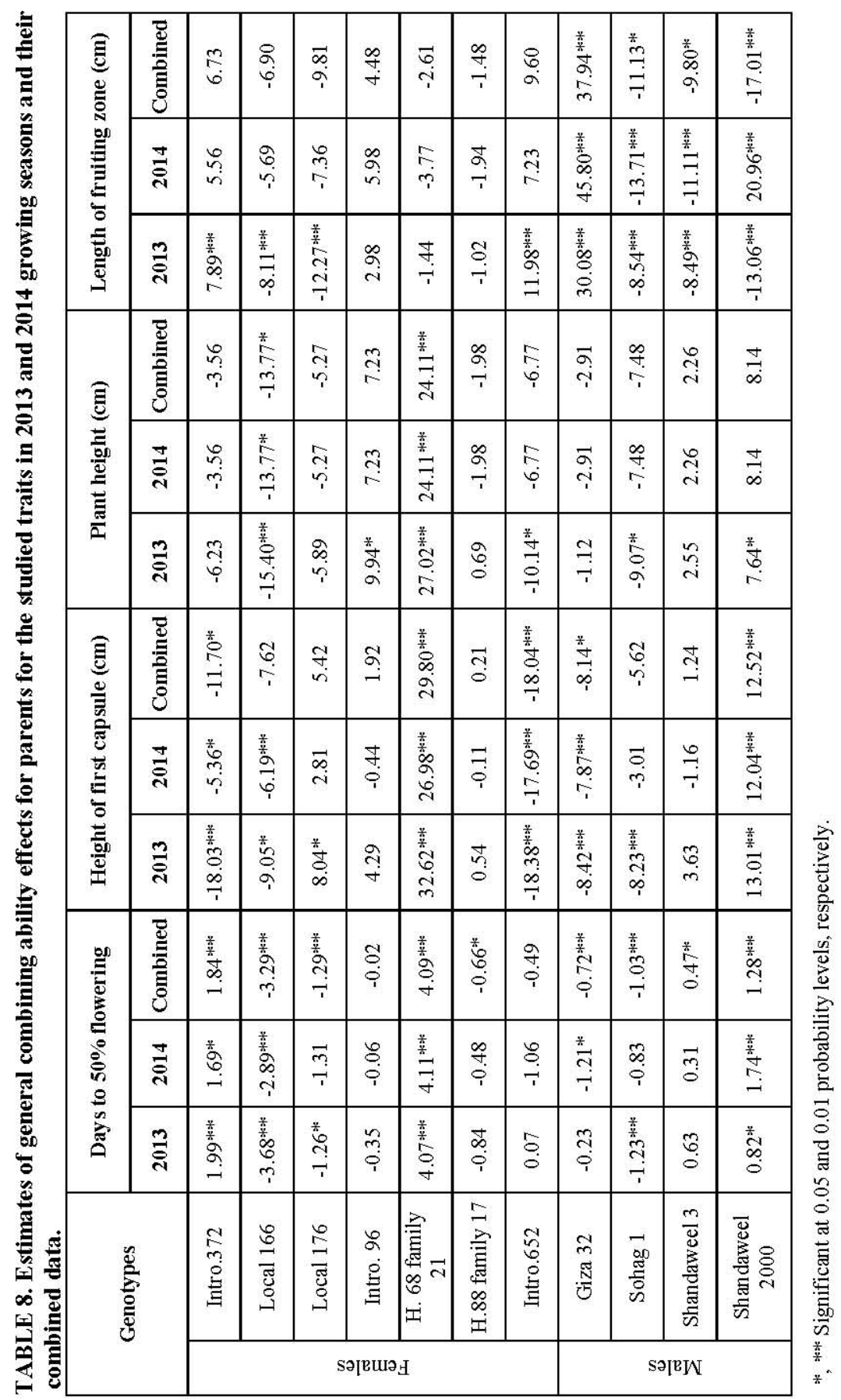

Egypt. J. Agron . 37, №. 2 (2015) 


\begin{tabular}{|c|c|c|c|c|c|c|c|c|c|c|c|c|}
\hline \multirow{3}{*}{ 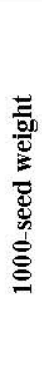 } & 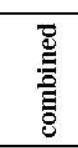 & 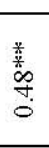 & 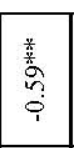 & $\frac{\stackrel{*}{*}}{\stackrel{+}{9}}$ & 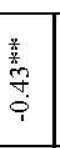 & 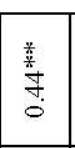 & $\stackrel{\vec{\leftrightarrow}}{i}$ & 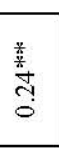 & $\stackrel{n}{0}$ & 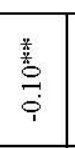 & 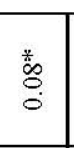 & 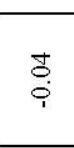 \\
\hline & ت্ت & 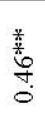 & $\begin{array}{l}\text { 童 } \\
\hat{n} \\
i \\
i\end{array}$ & $\stackrel{n}{9}$ & $\begin{array}{l}\text { 苂 } \\
\stackrel{0}{0}\end{array}$ & 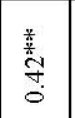 & $\stackrel{\text { }}{\stackrel{\leftrightarrow}{i}}$ & $\stackrel{7}{0}$ & $\stackrel{t}{\circ}$ & $\begin{array}{l}0 \\
\dot{i} \\
i\end{array}$ & $\stackrel{s}{\circ}$ & $\stackrel{\text { d: }}{\dot{\rho}}$ \\
\hline & $\stackrel{m}{\stackrel{M}{N}}$ & $\begin{array}{l}\text { 善 } \\
\vdots \\
0\end{array}$ & 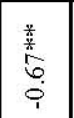 & $\begin{array}{l}\frac{.}{3} \\
\stackrel{9}{9} \\
\stackrel{0}{i}\end{array}$ & 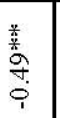 & 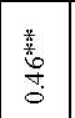 & $\stackrel{\overbrace{}}{\circ}$ & $\frac{\frac{.}{2}}{3}$ & $\stackrel{8}{\circ}$ & $\begin{array}{l}\text { 恶 } \\
\stackrel{7}{0}\end{array}$ & $\stackrel{\circ}{\circ}$ & $\stackrel{\text { }}{\stackrel{\leftrightarrow}{i}}$ \\
\hline \multirow{3}{*}{ 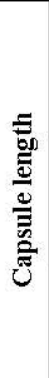 } & 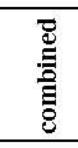 & તี & $\stackrel{5}{i}$ & $\stackrel{\circ}{\circ}$ & ণึ & $\stackrel{\overrightarrow{0}}{\circ}$ & $\stackrel{n}{i}$ & $\stackrel{7}{0}$ & 善 & $\begin{array}{l}\stackrel{*}{*} \\
\stackrel{\text { co }}{i}\end{array}$ & 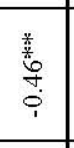 & $\begin{array}{l}\frac{*}{*} \\
\frac{1}{n} \\
\stackrel{0}{1}\end{array}$ \\
\hline & $\overrightarrow{\tilde{N}}$ & สิ & $\stackrel{5}{\dot{q}}$ & $\stackrel{\text { oे }}{\circ}$ & $\stackrel{\text { đે}}{i}$ & $\stackrel{\overrightarrow{0}}{\circ}$ & $\stackrel{2}{\stackrel{9}{i}}$ & $\stackrel{\overbrace{}}{0}$ & 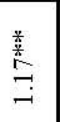 & $\begin{array}{l}\stackrel{*}{\circ} \\
\stackrel{i}{i} \\
\stackrel{i}{i}\end{array}$ & 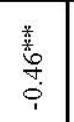 & $\begin{array}{l}\frac{0}{*} \\
\frac{1}{n} \\
\stackrel{1}{1}\end{array}$ \\
\hline & $\stackrel{m}{\stackrel{\sim}{N}}$ & 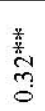 & 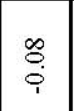 & $\frac{7}{i}$ & $\stackrel{\text { }}{\circ}$ & $\ddot{\circ}$ & 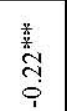 & $\stackrel{ \pm}{0}$ & 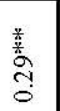 & $\stackrel{t}{0}$ & $\stackrel{\text { वे }}{\circ}$ & 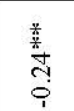 \\
\hline \multirow{3}{*}{ 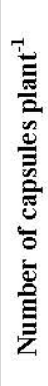 } & 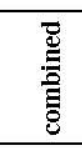 & 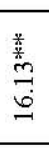 & 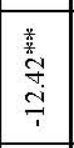 & $\stackrel{8}{8}$ & $\stackrel{m}{\stackrel{-}{0}}$ & $\stackrel{\leftrightarrow}{\circ}$ & $\stackrel{n}{\stackrel{n}{i}}$ & 蒙 & $\underset{\forall}{\stackrel{J}{*}}$ & $\begin{array}{l}\vec{t} \\
\vec{i}\end{array}$ & $\vec{T}$ & Fु \\
\hline & $\stackrel{\vec{N}}{\mathrm{~N}}$ & 喜 & 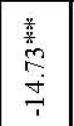 & $\begin{array}{l}\vec{\sigma} \\
\dot{\varphi}\end{array}$ & $\begin{array}{l}0 \\
\stackrel{0}{?} \\
i \\
1\end{array}$ & $\underset{⿱}{\stackrel{f}{+}}$ & $\exists$ & $\overrightarrow{7}$ & 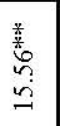 & 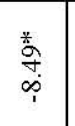 & $\begin{array}{l}: \\
\stackrel{0}{0} \\
\stackrel{0}{0} \\
i\end{array}$ & $\stackrel{\partial}{\circ}$ \\
\hline & $\stackrel{3}{\stackrel{\sim}{*}}$ & 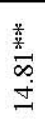 & $\begin{array}{l}\stackrel{*}{7} \\
\stackrel{0}{\frac{1}{1}}\end{array}$ & के & 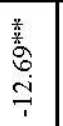 & $\begin{array}{l}\frac{\vec{*}}{\vec{*}} \\
\vec{\infty} \\
\dot{J} \\
\dot{J}\end{array}$ & $\begin{array}{l}\vec{b} \\
\dot{\varphi}\end{array}$ & $\begin{array}{l}\infty \\
\stackrel{\sim}{\sim}\end{array}$ & $\begin{array}{l}\text { oे } \\
\text { ب. }\end{array}$ & $\vec{I}$ & 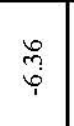 & 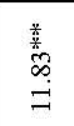 \\
\hline \multirow{3}{*}{ 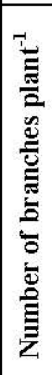 } & 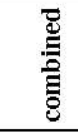 & 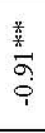 & $\overline{0}$ & $\stackrel{m}{0}$ & $\begin{array}{l}6 \\
0\end{array}$ & $\stackrel{m}{0}$ & 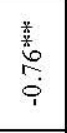 & 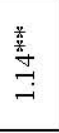 & $\begin{array}{l}\text { 舎 } \\
\stackrel{3}{\rightarrow}\end{array}$ & 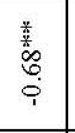 & 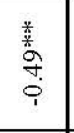 & 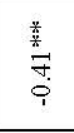 \\
\hline & ثั & సิ & $\stackrel{5}{i}$ & $\stackrel{8}{8}$ & ণָ & $\stackrel{\overrightarrow{0}}{\circ}$ & $\stackrel{2}{\stackrel{0}{i}}$ & $\overparen{7}$ & $\stackrel{\text { 善 }}{\leftrightarrows}$ & 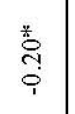 & 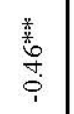 & $\begin{array}{l}\frac{.}{3} \\
\stackrel{5}{5} \\
i \\
i\end{array}$ \\
\hline & $\stackrel{m}{\stackrel{\sim}{*}}$ & 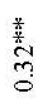 & $\stackrel{\infty}{\circ}$ & $\begin{array}{l}= \\
\dot{c}\end{array}$ & $\stackrel{\text { }}{9}$ & $\stackrel{\overrightarrow{0}}{\circ}$ & đ઼̆ & $\underset{0}{ \pm}$ & 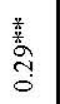 & $\stackrel{t}{0}$ & $\begin{array}{l}\stackrel{0}{0} \\
\dot{0}\end{array}$ & $\begin{array}{l}+ \\
\stackrel{m}{2} \\
\stackrel{i}{i}\end{array}$ \\
\hline \multicolumn{2}{|r|}{ 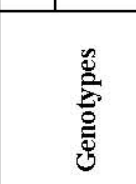 } & 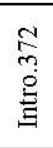 & త్ర్ & 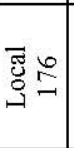 & 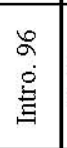 & 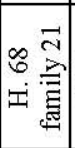 & 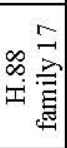 & 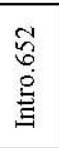 & 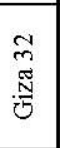 & 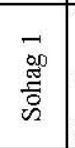 & 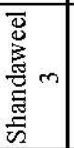 & 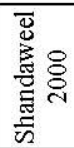 \\
\hline
\end{tabular}

Egypt. J. Agron . 37, No.2 (2015) 


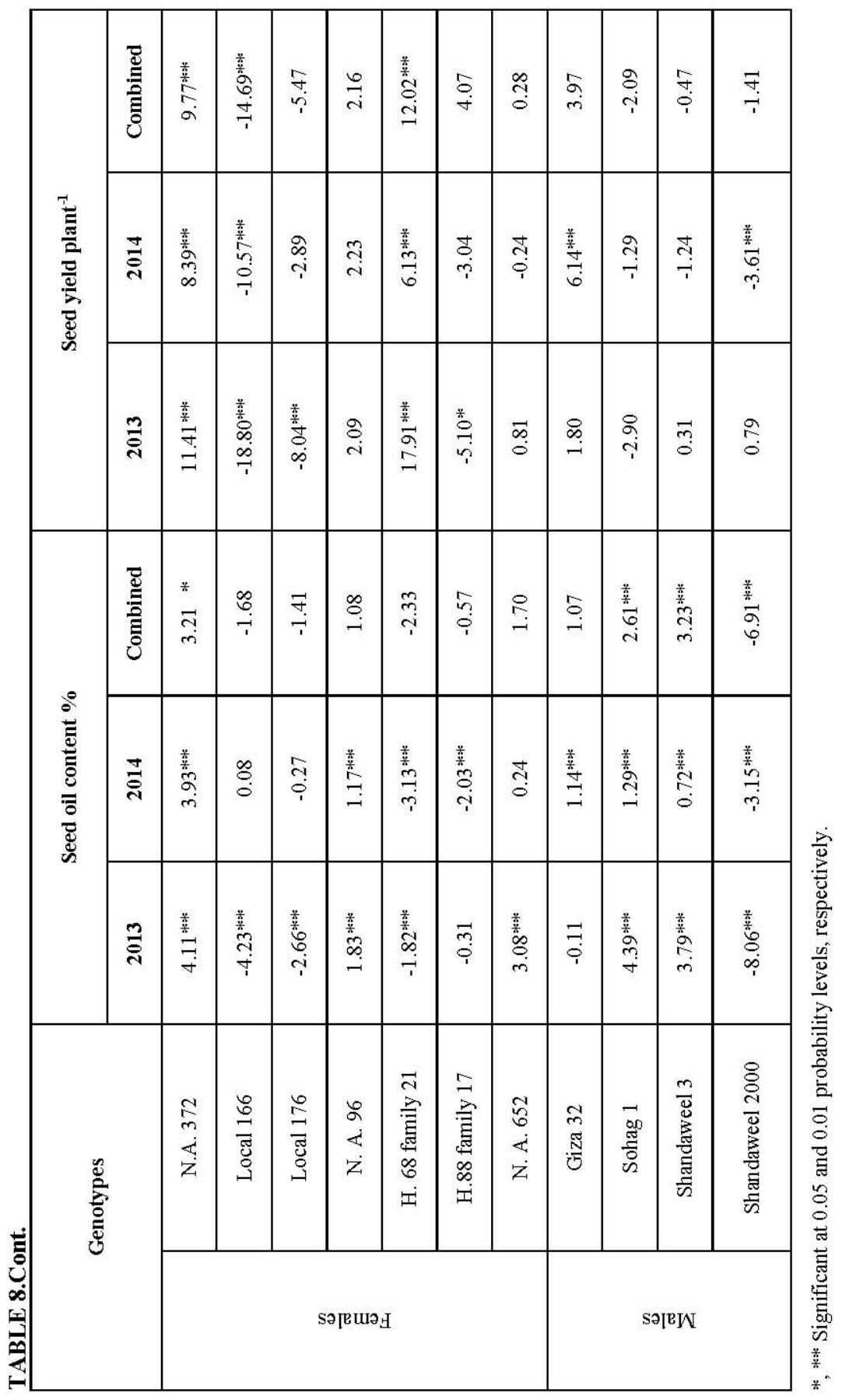

Egypt. J. Agron . 37, No. 2 (2015) 
The results of GCA effects of parental lines showed that the female lines N.A. 372 and H. 68 family 21 in the two seasons and their combined were the best general combiners for increasing seed yield plant ${ }^{-1}$. Among male parents Giza32 in 2014 season was good general combiners. From the results obtained here, it can be concluded that N.A. 372 and H. 68 family 21 among female parents and Giza 32 among male parents were good general combiners for improvement most studied traits. Similar results were obtained by Mishra \& Sikarwar (2001), Krishna et al. (2002), El-Shakhess (2003), Uzun et al. (2004), El-Shakhess \& Khalifa (2007), El-Shakhess et al. (2009), Abdelaziz et al. (2010), Sedeck \& Shafie (2013) and Hassan \& Sedeck (2015). They found that significant general combining ability effects in some parental lines for some studied traits.

\section{Specific combining ability (SCA) effects}

Estimates of specific combining ability (SCA) effects for crosses for the studied traits in 2013, 2014 seasons and their combined are listed in Table 9. Results of combined data over the two years for days to $50 \%$ flowering showed that the best combinations were Shandaweel $3 \times$ Local $176(-3.77 * *)$, Shandaweel 2000 x N.A.96 (-3.16**) and Sohag 1 X N.A. $372(-2.89 * *)$ had significant negative SCA values. These results suggested that these crosses may be considered earlier than the other combinations. Among crosses, Shandaweel 2000 x H.88 Family $17(-19.50 *)$ was found to the best combination over two seasons for height of first capsule. For plant height, the cross Shandaweel $3 \times$ local 176 recorded significant negative SCA estimate $\left(-24.40^{*}\right)$ over the seasons. Estimates of SCA for length of fruiting zone over seasons indicate that the best cross was Shandaweel $3 \times$ N.A.96. Results also revealed that the crosses Shandaweel $2000 \times$ N.A.372, Sohag $1 \times$ H.88 family 17 and Shandaweel $2000 \times$ local 176 were the better over seasons for number of capsules plant ${ }^{-1}$. However, highly significant and significant negative effects over two years were by Sohag $1 \times$ local $166\left(-30.40^{* *}\right)$ and Shandaweel $2000 \times$ H. 68 Family $21\left(-21.08^{*}\right)$. Data over two seasons also indicated that, the cross Giza $32 \times$ N.A 372 was the best for capsule length. Out of the 28 crosses, Shandaweel $2000 \times$ Local 176, Shandaweel 3 x H.88 Family 17, Shandaweel $3 \times$ H.68 Family 21, Sohag $1 \times$ H.68 Family 21, Sohag $1 \times$ Local 166 , Giza $32 \times$ N.A. 96 and Giza $32 \times$ N.A.372 were the desirable combinations over two seasons for 1000 - seed weight. On the other side, negative SCA effects over two seasons ranged from significant to high significant were obtained by four crosses for seed oil content percentage. Concerning seed yield plant $^{-1}$, the crosses Shandaweel $3 \times$ N.A.96, Shandaweel $2000 \times$ Local 176, Giza $32 \times$ N.A. 372, Sohag $1 \times$ Local 166, Sohag $1 \times$ H.68 Family 21, Shandaweel $2000 \times$ H.88 Family 17 and Giza $32 \times$ Local 176 were the best combinations over two seasons. Generally, it can be clearly noticed that desirable SCA effects were obtained for most studied traits. On the other side, the parents involved in most the best crosses were found to have high $\times$ high, high $\times$ low, low $\times$ high and low $\times$ low GCA status. In this concern, desirable significant SCA effects were also obtained by Kadhusudan \& Nadaf (2009) for some studied traits.

Egypt. J. Agron. 37, No.2 (2015) 


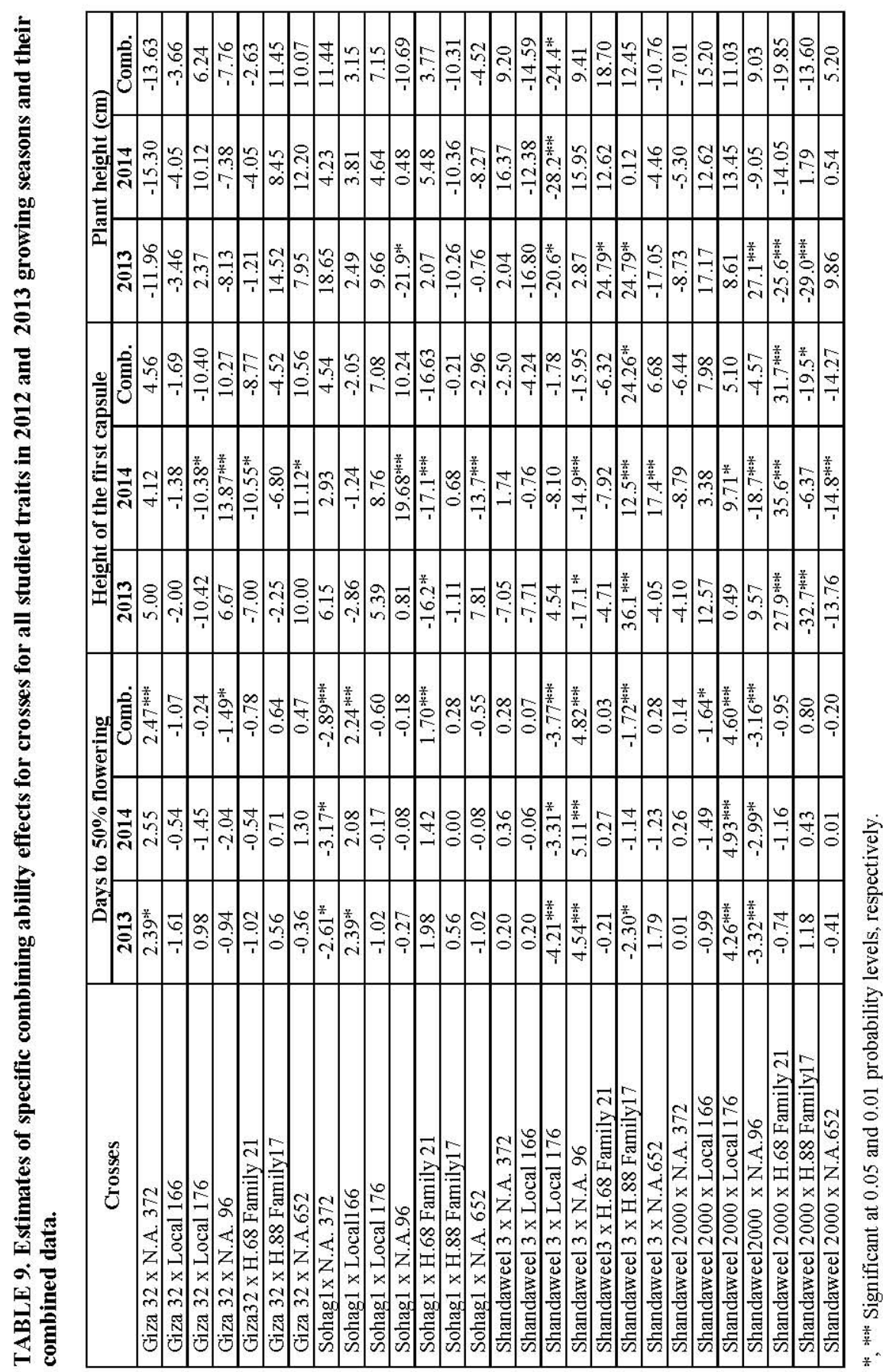

Egypt. J. Agron . 37, No. 2 (2015) 


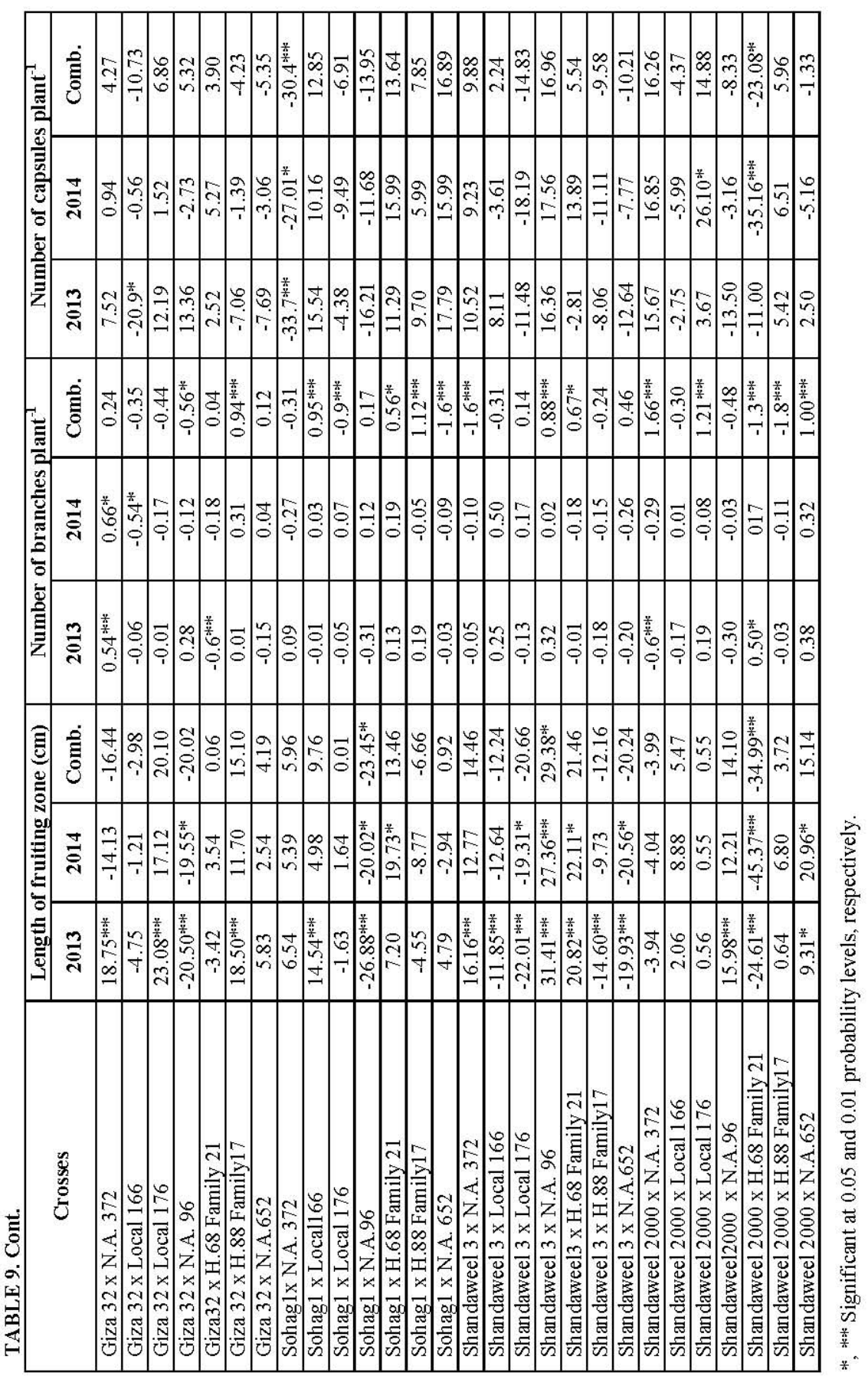

Egypt. J. Agron . 37, No.2 (2015) 


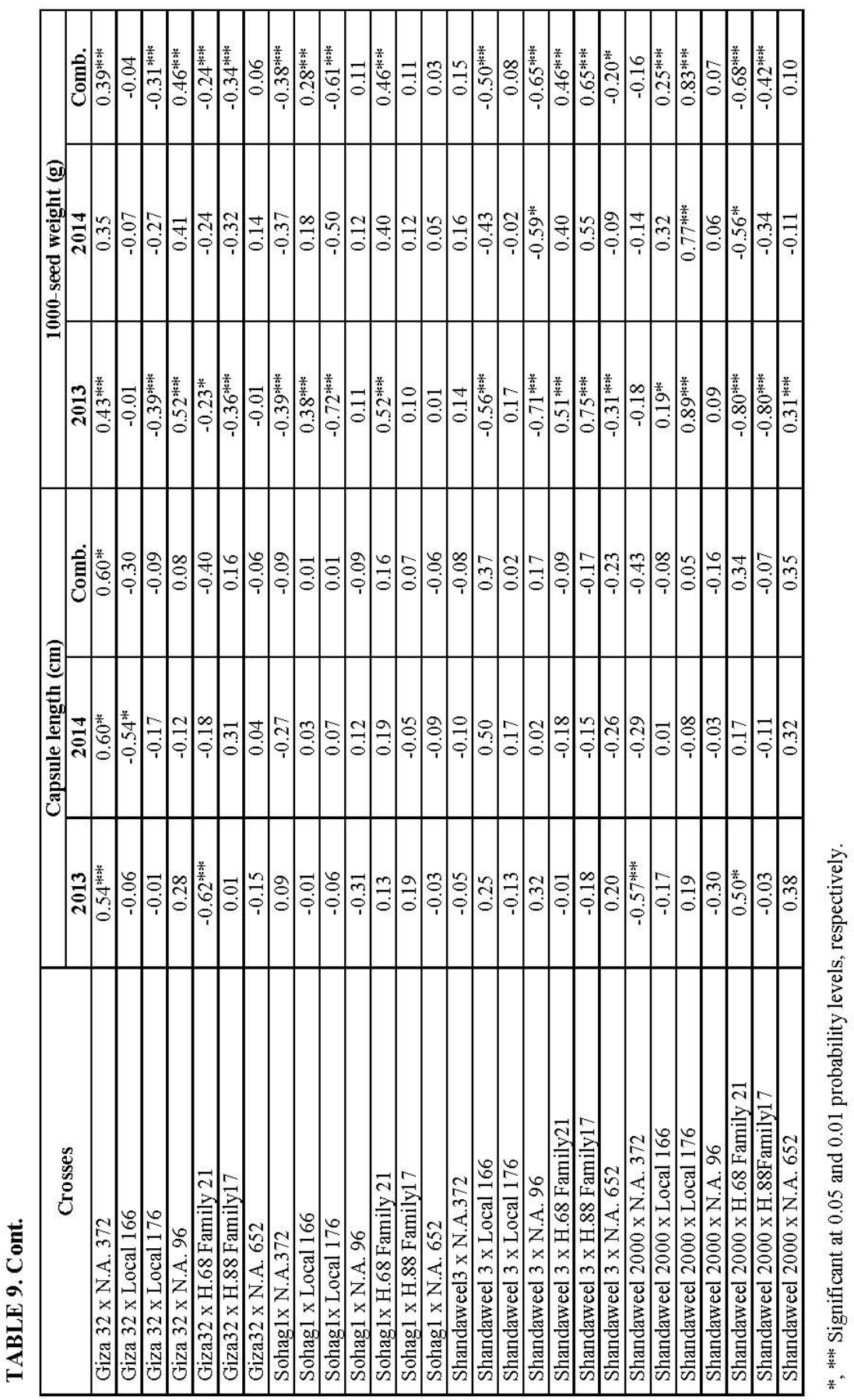

Egypt. J. Agron . 37, No. 2 (2015) 


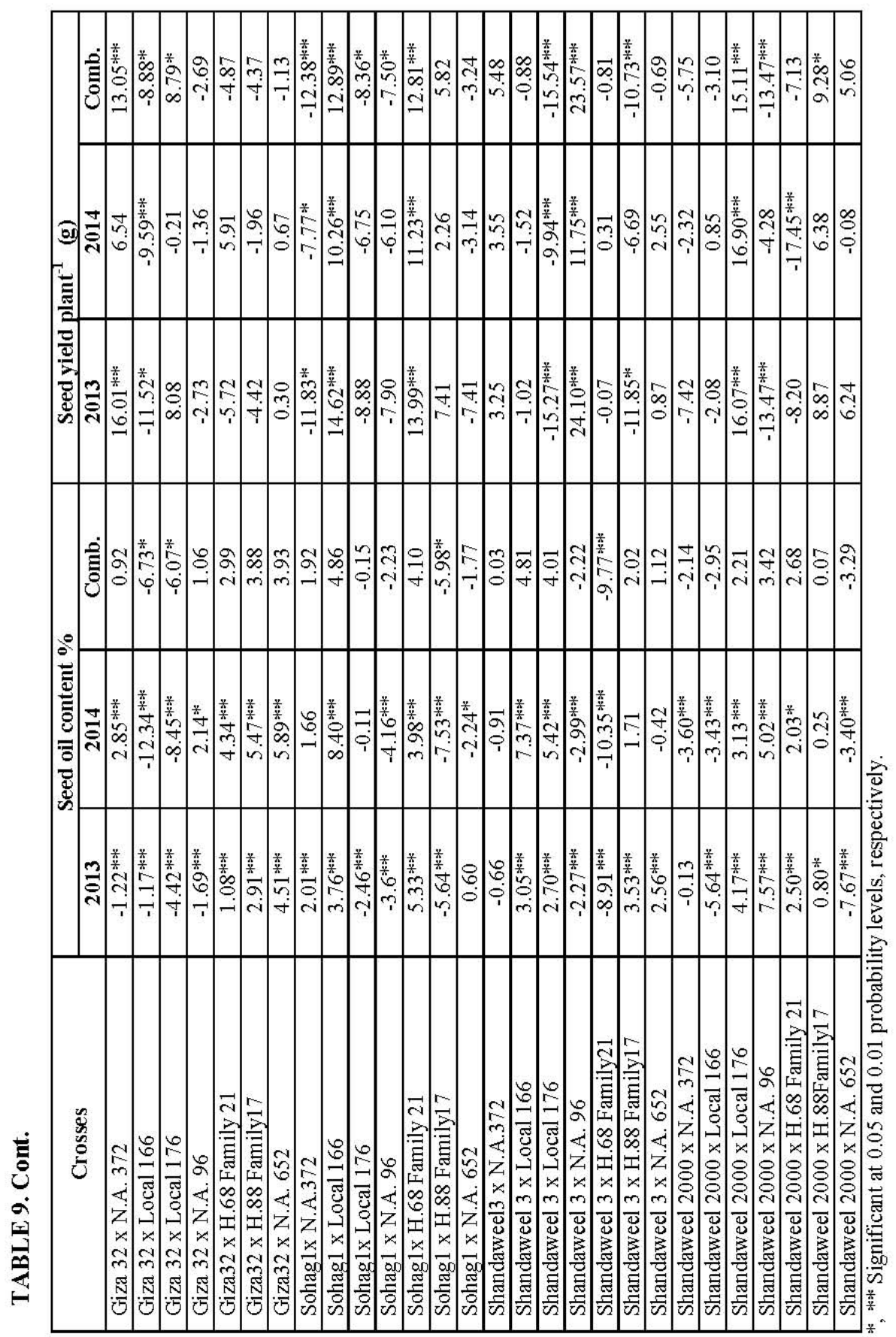

Egypt. J. Agron . 37, No.2 (2015) 


\section{Conclusion}

Finally, it can be concluded that the parents N. A. 372, H.68 family 21 and Giza 32 were good combiners for improvement most studied traits. Also, desirable SCA effects were obtained for most studied traits. The crosses; Shandaweel $3 \times$ N. A. 96, Shandaweel $2000 \times$ Local 176, Giza $32 \times$ N. A. 372, Sohag $1 \times$ Local 166 and Sohag $1 \times$ H. 68 Family 21 had most desirable SCA effects for seed yield plant ${ }^{-1}$.

\section{References}

Abdelaziz, Ghada B., Abu El-Ezz, A.A. and El-Shakhess, Samar A.M. (2010) Heterosis and combining ability for seed yield and its components in sesame under stress conditions. Egypt. J. Plant Breed. 14 (2), 59-70.

AOAC (1980) "Official Method of Analysis" of the Association of Official Agriculture Chemists. $13^{\text {th }}$ ed., AOAC, Washington, DC., USA.

Attia, S.A.M., El-Shakhess, Samar, A.M. and Madkour, M.A. (2004) Genetic analysis of yield and its components in sesame. Egypt. J. Genetic. Cytol. 33, 33-43.

Banerjee, P.P. and Kole, P.C. (2009) Combining ability analysis for seed yield and some of its component characters in sesame (Sesamum indicum L.). Intern. J. of Pl Breeding and Genetics, 3 (1),11-21.

Bhatt, G.M. (1971) Heterosis performance and combining ability in diallel crosses among spring wheat. (T. aestivum. L ). Australian J. Agric. Res. 22, 359 - 369.

Devasena, N., Muralidharan, V. and Punitha, D. (2001) Studies on combining ability for yield related traits in sesame (Sesamum indicum L.). Research on Crops. 2 (3), 409-413.

Donghwi, K., Chulwhan, K., Kang, S., Changhwan, P., Sungwoo, L. and Naksul, S. (2006) Genetic variance and combining ability of shattering and growth characters in sesame. Korean J. Crop Sci. 51 (7), 652-657.

El-Ahmar, B. A., Sherif, S.A., Shabana, R. and El-Shakhess, Samar, A.M. (1996) Gene action and heritability estimates in sesame (Sesamum indicum L.) crosses. Egypt J. Agric. Res. 74(2), 371-381.

El-Shakhess, Samar. A. M. (2003) Heterosis and inbreeding depression in sesame. Egypt. J. Plant Breed. 7 (1), 487-506.

El-Shakhess, Samar A. M. and Khalifa, M.M.A. (2007) Combining ability and heterosis for yield, yield components, charcoaLI rot and Fusariam wilt disease in sesame. Egypt. J. Plant Breed. 11 (1), 351-371.

El-Shakhess, Samar A.M., Sedeck, F.Sh. and El-Shimy, A.A. (2009) Genetic analysis of sesame yield via quadarallel mating system (Sesamum indicum L.). Egypt. J. Genet. Cytol. 38, 55-71. 
F.A.O. (2013) Food and Agriculture Organization of the United Nations, World production and imports. Statics of Vegetable oils.

Gawade, S.A., Banger, N.D., Pattil, C.M. and Nikam, A.S. (2007) Combining ability analysis for yield and its components in sesame (Sesamum indicum L.). Research on Crops, 8 (2), 492-495.

Hassaballa, E.A., Bakheit, B. R., Abdallah, M. M. and Abd El-Motagally, F. M. (1996) Combining ability of seed yield and its components in sesame (Sesamum indicum L.). Assiut J. Agric. Sci. 27, 43-56.

Hassan, M.S. and Sedeck, F. Sh. (2015) Combining ability and heterosis estimates in sesame. World Applied Sciences Journal, 33 (5), 690-698.

Kadhusudan, Y.K. and Nadaf, H. L. (2009) Combining ability and gene action for yield and yield components in sesame (Sesamum indicum L). Karnataka J. Agric. Sci. 22 (2), 225-260.

Kar, U. C., Swain, D. and Mahapatra, J. R. ( 2002) Hybrid performance in relation to combining ability analysis for yield and its components in sesame (Sesamum indicum L.). Research on Crops 3 (1), 103-109.

Krishna Devi, M., Tnirugnana Kumar, S. and Ganesan, J. (2002) Combining ability and heterosis for reproductive efficiency in sesame (Sesamum indicum L.). Sesame and Safflower Newsletter, 17, 5-9.

Kumar, S., Puspha, T. R., Karuppiah, P. and Ganesan, J. (2004) Studies on combining ability in sesame (Sesamum indicum L.). Crop Research Hisar. 27 (1), 99103.

Kumar, S.T., Kumar, N.S., Eswaran, R., Anandan, A., Ganesan, J. and Thangavelu, S. (2006) Breeding concepts ascertained from experiments on sesame (Sesamum indicum L.). Research on Crops, 7 (1), 229-237.

Manivannan, N. and Ganesan, J. (2001) Line x tester analysis in sesame (Sesamum indicum L.). Indian Journal of Agricultural Research, 35 (2), 90-94.

Mishra, A. K. and Sikarwar, R. S. (2001) Heterosis and combining ability analysis in sesame. Sesame and Safflower Newsletter ,16, 1-5.

Nijagum, H.G., Parameshwarappa, K.G. and Salimath, P. M. (2002) Studies on combining ability for exploitation of hybrid vigor in sesame. Crop Research Hisar. 23 (3), 522-525.

Ramesh, S., Sheriff, R.A., Rao, A.M. and Reddy, S.S.L. (2000) Line x tester analysis of quantitative traits in sesame (Sesamum indicum L.). Mysore J. Agri. Sci. 34 (4), 308310 .

Shabana, R., El-Ahmear, B.A., Shrief, S.A. and El-Shakhess, Samar A.M. (1996) Combining ability and heterobeltiosis in crosses among local and exotic sesame (Sesamum indicum L.) cultivars. Egypt J. Agric. Res. 74 (2), 357-369.

Egypt. J. Agron . 37, No.2 (2015) 
Sanker, P.D. and Kumar, C. R. A. (2003) Combining ability studies on economic traits in sesame (Sesamum indicum L.). Indian J. of Res. 37 (3), 223-226.

Saravanan, S. and Nadarajan, N. (2003) Combining ability studies in sesame. Crop Res. 25 (2), 319-324.

Sedeck, F. Sh. and Shafie, Wfaa W.M. (2013) Estimates of gene action and interrelationships among yield characters in diallel crosses of sesame (Sesamum indicum L.). Assiut J. Agric. Sci. 44 (3), 15-31.

Singh, R.K. and Chauadhary, B.D. (1985) "Biometrical Methods in Quantitative Genetic Analysis”, Kalyani Pub., New Delhi, India.

Steel, R. G. D. and Torrie, J. H. (1980) "Principles and Procedures of Statistics". Mc Grow-Hill Book Co., Inc., New York.

Sumathi, P. and Kalaimani, S. (2000) Combining ability studies for yield and its attributes in sesame. Madras Agricultural J. 87 (70/12), 445-650.

Taher, H. M. and El-Samanody, M. K. M. (2006) Combining ability and heterosis for seed yield and its components in sesame. Egypt. J. Plant Breed. 10 (2), 51-63.

Uzun, B.M., Ozbas, O., Canci, H. and Cagirgan, M.I. (2004) Heterosis for agronomic traits in sesame hybrids of cultivars $\mathrm{x}$ closed capsule mutants. Actu. Agri. Scandinavia section. B, Soil and Plant Sci. 54 (2), 108-112.

Vidhyavathi, R., Manivannan, N. and Muralidharan, V. (2005) Line x Tester analysis in sesame (Sesamum indicum L.). Indian J. Agri. Res. 39 (3), 225-228.

(Received 10/6/2015; accepted 23/8/2015) 


\section{تحليل السلالة × الكثاف لصفة المحصول ومكوناته فى السمسم}

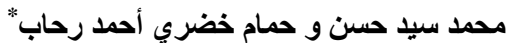

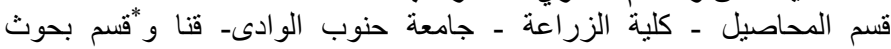

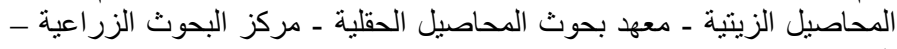

$$
\begin{aligned}
& \text { القاهرة- مصر. }
\end{aligned}
$$

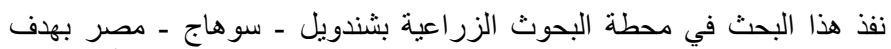

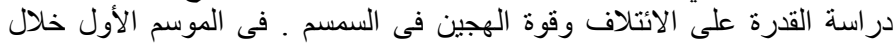

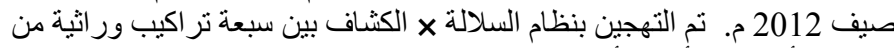

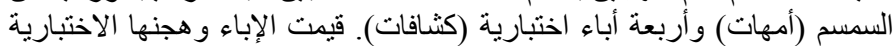

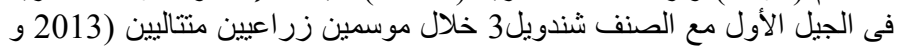

أظهر التحليل المشترك للتباين عبر الموسمين معنوية عالية بين التراكيب

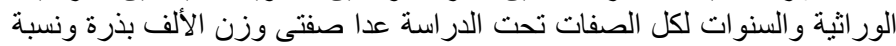

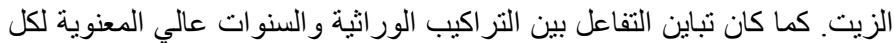

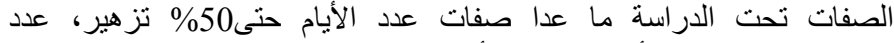

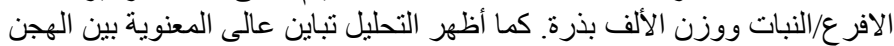

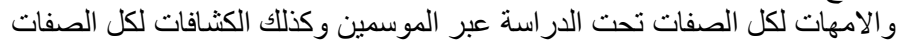

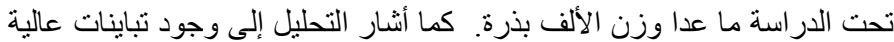

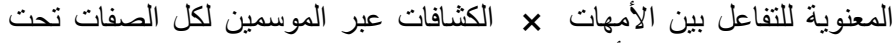

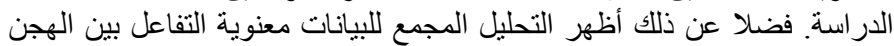

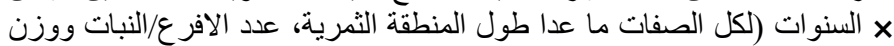

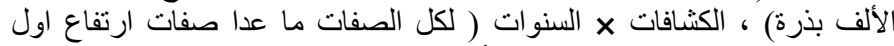

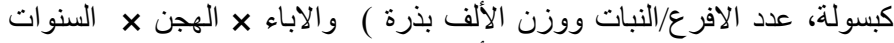

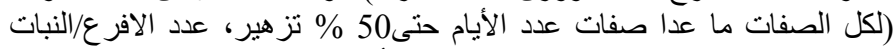

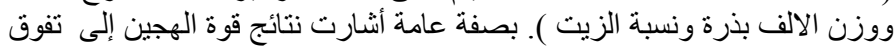

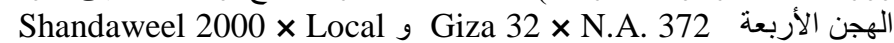
Shandaweel 2000 و Shandaweel 2000 × H. 68 Family 21 × 176

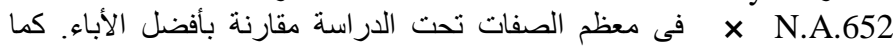

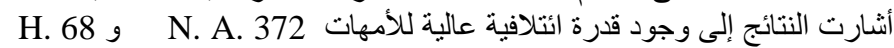

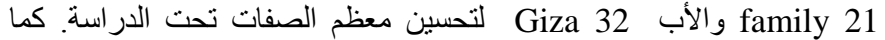

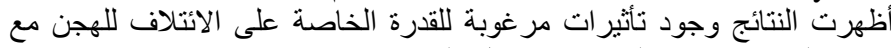

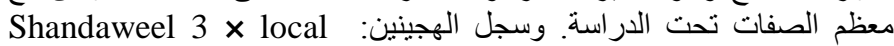

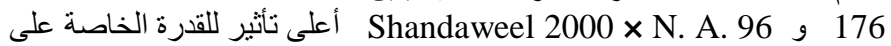

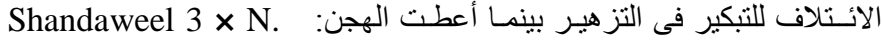
Giza $32 \times$ N. A. 372 , Shandaweel $2000 \times$ Local 176 و A. 96 Sohag $1 \times$ H. 68 Family 21 , Sohag $1 \times$ Local 166, التأثير الأعلى لصفة محصول البذور للنبات. 